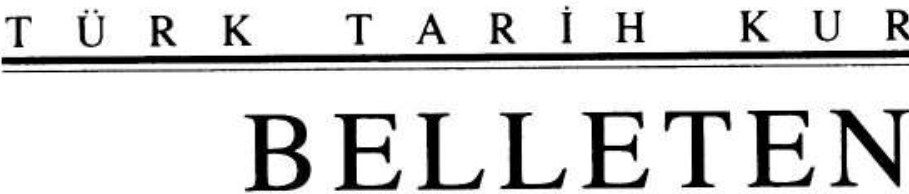

\section{UŞAK MÜZESINDEKI KISTOPHORIK DAMGALI SIDE TETRADRAHMI DEFINESI}

\section{MELİH ARSLAN ${ }^{*}$}

Bu define, Uşak Müze Müdürlüğü tarafindan 01.11.1995 tarihinde Ahmet Arslan isimli bir kişiden satın alınmışur. Definenin, Afyon İli, Sandıklı İlçesi, Hocalar ${ }^{1}$ Kasabasında (Bkz., Harita 2) bulunduğuna ilişkin müze envanter defterinde kayıt vardır. 19 adet gümüș Side tetradrahmisi'nden oluşan bu önemli definenin tümünün bu kadar olmayacağımı düşünmekteyiz, çünkü defineyi müzeye satan kişinin profesyonel bir antikacı olduğunu öğrendik. Bu nedenle definenin parçalandığını düşünüyoruz. Ahmet Arslan definenin sadece 16 sikkesini müzeye satmıștur. Akabinde, bir başka antikacı Zeki Erdem tarafından, bu definenin 3 adet sikkesi Uşak Müzesine satılmışur². Böylece definenin Uşak Müzesi'ndeki 19 adeti tamamlanmıștur. Define, şimdi müzenin sikke teşhirinde olup, Hocalar Definesi adıyla sergilenmektedir.

Bu defineyi Uşak Müze Müdürlüğü'nde 2006 Nisan ayında gördük ${ }^{3}$ ve bu konuda daha önce birkaç yayın çalışmamız olduğundan ve nümizmatik

- Melih Arslan, Anadolu Medeniyetleri Müzesi, 06240 Hisar/Ankara; e-mail: arslanmelih06@hotmail.com

${ }^{1}$ Definenin, bugünkü adıyla Dolay Höyükten çıktığını müze kayıtlarından öğrendik. Bu hōyük, Phrygia - Diokleia antik kenti olarak lokalize edilmektedir.

2 Defineye sonradan dahil olan bu 3 sikke için bkz., katalog no. 3 (env. 12197), no. 10 (env. 12198) ve no. 19 (env. 12199).

${ }^{3} 2006$ yllında tüm Türkiye ve dünya Uşak Müzesi'ndeki talihsiz ve biz müzecileri üzen bir olayı konuştu, işte bu kötü olayın soruşturması için görevli olarak Uşak Müzesi'nde bulunduğum bir sırada, bu enteresan defineyi gördüm, inceledim ve burada yayımlayarak sizlerle paylaşmak istedim. Çalışmalarım esnasında yardımlarını görmüş olduğum Uşak Müzesi Arkeolog'larından Sn. Sabiha Pazarcı'ya, Sn. Sadık Doğan'a ve Sn. Birol Güngòr'e, ayrıca resim levhalarının düzenlenmesindeki yardımından dolayı Arkeolog $\mathrm{Sn}$. Ali Yalın Turan'a teşekkürü bir borç bilirim. 
bilim dünyası için önemli bir belge değeri taşıdığından bu definenin yayımlanmasının gerekli olduğuna karar verdik. Bunun için yerinde lazım olan belgeleme çalışmalarımı yaptık. Define sikkeleri çok yıpranmıș ve yüzeyleri farklı renkteki gümüş kararmasına maruz kalmış olduğundan orijinal resimlerin iyi görüntü vermeyebileceği kuşkusuyla, tüm sikkelerin mülajlarımı aldık ve bunlardan alçı kalıplar çıkartarak daha net fotoğraflar elde etmeye çalışuk. Buradaki resim levhalarımızda, definenin hem orijinal, hem de alçı kalıplarından fotoğraflarını beraberce verdik.

Defineyi, diğer Side definelerinden farklı ve önemli kılan özellik, define sikkelerinden 19 nun 10 u üzerinde, bilim dünyasınca kontrmark (karșı damga) olarak bilinen işaretlerin bulunmasıdır. Bu damgalardan 8 i, Pergamon Krallığını sembolize eden, "kılıfı içinde yay" ve diğer ikisi ise bu krallı̆̆ın çağdaşı ve ezeli düșmanı olan Suriye Krallığını sembolize eden "gemi çıpası" motifidir.

Side'nin yeni tip tetradrahmilerinin en erken basımlarmndan oluşan bu definenin, diğer bir önemli özelliği ise, 19 sikkenin 14 ü farklı magistrat (sikke basımından sorumlu yetkili memur) isimleri taşımasıdır.

Side darphanesi bu tip gümüş sikkeleri, ilk kez, M.Ö. 205 tarihinde darp etmeye başlamıştur. Side'nin bu tetradrahmileri ve drahmilerinin, dört ayrı zaman dilimi içerisinde basıldıkları kabul edilmektedir. Bu dört serinin bașlangıç ve bitiş tarihleri aşağıda gösterildiği șekildedir:

1. Seri: M.Ö. 205-200

2. Seri: M.Ö. 200-190

3. Seri: M.Ö. $188-175$

4. Seri: M.Ö. $155-36$

Uşak Müzesi, Hocalar Definesi sikkelerinin tümü, ilk iki serinin basımlarındandır. Katalog içerisinde görüleceği üzere, 6 sikke ilk seriyi oluşturan 205-200 yıllarından, diğer 13 sikke ise, 2. seriden olup, 200-190 yıllarındandır. Böylece define sikkeleri, ilk 15 yıllık dönem içerisinde basılmıştur.

Side darphanesi (Antalya - Manavgat İlçesi, Selimiye Köyü, bugünkü Side Kasabası): Pamphylia bölgesinin en önemli liman kenti olan Side, Melas (Manavgat) Irmağı'nın denize döküldüğü yerin birkaç mil batısında kurulmuştur. Kentin adının anlamı Grekçe nar olup, Nar aynı zamanda șehrin 
sembolüdür. Bu sembol sikkeler üzerinde daima yer almaktadır. Nümizmatikte bu tür sikkelere "konuşan sikkeler" denilmektedir. Pamphylia kentleri içinde Side ve Aspendos en erken sikkeyi basmıs olan kentlerdendir. Kentin M.Ö. 5. yüzyıldaki ilk staterlerinin ön yüzünde nar, arka yüzünde ise quadratum incusum (kare çukur) içinde bazen tek, bazen çift yunus balığı betimlenmiştir' ${ }^{4}$. M.Ö. 4. yüzyıldaki staterlerinde ön yüzde ayakta duran Athena, arka yüzde ise ayakta Apollon, bazen çıplak, bazen de kısa khiton giymiş ve önünde yuvarlak bir sunak ile resmedilmiştir. Şehrin 5. yüzyıldan 3 . yüzyıl sonuna kadar olan bu gümüş basımları Pers standardındadır. Bu Pers ağırlık birimindeki (standardındaki) sikkelerin üzerindeki yazıt anlaşılmaz bir dil olup, upkı Aspendos sikkelerinde olduğu gibi yerli Pamphylia lehçesinde yazılmıștır. Şehir M.Ö. 205-36 yılları arasında burada örnekleri görülen Attika standardındaki gümüş paralarını (tetradrahmi ve drahmi) basmıştur. Bu yeni tetradrahmiler tüm Doğu Akdeniz ticaretinde en aranan para olmuşlardır. Bu makbul gümüş paraların ön yüzünde korint miğferli Athena başı, arka yüzde sola yürüyen, çelenk taşıyan Nike betimlenmiştir. Arka yüzde sikkenin sol boşluğunda daima şehrin sembolü nar ve değişen yetkili memur (magistrat) isimleri bulunur.

Side'nin gümüş tetradrahmilerinin basımlarının M.Ö. 36 yılında sona ermiş olduğu ve Side darphanesinin Side adına sikke basmamıș olduğu birçok araştırmacı tarafından söylenmesine rağmen, bu tetradrahmilere ait bir ön yüz kalıbının, M.Ö. 36-25 yılları arasında Side şehrinde, Galatia Kralı Amyntas adına bastırılmış krali tetradramilerde görüldüğü belirlenmiştir. Kentin idaresinin M.Ö. 36 yılı bașından itibaren Romalılarca Galatia Kralı Amyntas'a (36-25) bırakılması nedeniyle kent ön yüzde tamamen aynı ve arka yüzde çok az farklılıkla (arka yüzde, Nike ve magistrat isimleri korunmuş) olmak üzere, BA I $\Lambda E \Omega \Sigma$ AMYNTOY (kral Amyntas) yazısı ile, sola yürüyen Nike sağ elinde çelenk yerine kurdela sarılı krallık asası taşımaktadır ${ }^{5}$. Böylece Side tetradrahmileri M.Ö. 25 yılına kadar basılmışlardır diyebiliriz.

Strabon, Side'nin Aeolis-Kyme şehrinden gelen kolonistlerce kurulduğunu söylemektedir. Arrianus'a göre ise, Kyme'den gelen Grekli kolo-

\footnotetext{
'Side'nin erken basımları için bkz., S. Atlan, Side'nin Milattan Önce V. ve IV. Yüzyl Sikkeleri Üzerinde Araşurmalar-Antalya Bölgesinde Araşurmalar 7. Ankara 1967.

${ }^{5} \mathrm{~S}$. Atlan, "Side'de basılan Amyntas sikkeleri - Die Münzprägung des Amyntas in Side". Belleten 39/156. Ankara 1975: 575-611 ve M. Arslan, Galatya Krallığı ve Roma Dönemi Ankyra Sehir Sikkeleri sThe Coins of Galatian Kingdom and The Roman Coinage of Ancyra in Galatia. Ankara Ticaret Odası Yayınları (Ankara 2004) : 29-31 (levha I, no. K6).
} 
nistler ve yerli halk karışıp anlaşılmaz bir dil konuşmaya başlamışlardır. İște bu dil Pampylia dilidir. Bu dil Roma devrinde tamamen unutulmuștur. Bu yüzden kentin klasik ve erken Helenistik sikkeleri bu dil ile yazılmıșken geç Helenistik ve Roma dönemi darplarında bu dil terk edilmiştir. Helenistik çağda Küçük Asya'nın güney kıylarındaki en önemli darphanelerinden biri olan Side, Roma çağında bu özelliğini yavaş yavaş kaybetse de, kentin Roma devri bronz sikkeleri Pamphylia kentleri içinde en zengin çeșidiyle yine ön plandaki yerini korumaktadır. Roma dönemi sikke basımlanı imparator Tiberius'tan (M.S. 14-37) Aurelianus'a (M.S. 270-275) kadar çok geniş sürede basımlarını sürdürmüșlerdir ${ }^{6}$.

Side Tetradrahmi Defineleri: Attika ağırlık biriminde (17.00 gr.) basılmış olan Side'nin bu tetradrahmileri Geç. Helenistik dönem için Anadolu ve Doğu Akdeniz'e kıyısı olan bölgelerde çok sevilerek kullanılmış olduğu bilinmektedir. Bu gümüş sikkeler Anadolu'nun batısından başlayarak, Güney-Doğu Türkiye ve Doğu Akdeniz'e kıyısı olan memleketlerde (Syria Krallığı toprakları içinde, Syria, Mesopotamia, Babylonia ve Finike gibi yörelerde) bulunmuş diğer definelerle beraber veya tek başına ele geçmişlerdir (Bkz., harita la ve 1b). Pamphylia bölgesi ve bölgenin komşusu antik bölgelerin müzeleri başta olmak üzere Türkiye Müzelerinde tek tek bulunmasına rağmen, define olarak ise daha az sayıdaki müze koleksiyonunda bulunmaktadır. Antik Akdeniz dünyasının Bergama Krallığı Kistophorik gümüş paraları ile beraber en geçerli parası olan Side Tetradrahmileri define olarak Türkiye Müzelerinde 1980 yilı öncesinde çok az sayıda bulunuyordu. Bu tarihten önce bulunanların bir kısmı da Avrupa Müzelerinde veya özel koleksiyonlarında bulunmaktadır. Biz bu makale ile birlikte Türkiye Müzelerindeki beșinci Side Tetradrahmi Definesini yayımlamaktayız. Antalya Müzesi 4 adet Side Tetradrahmi Definesi ile en büyük koleksiyona sahiptir. Bunlardan ilk üçü bizim tarafimızdan ${ }^{7}$ ve dördüncüsü ise, F. Büyükyörük tarafindan 2001 yilında yayımlanmıștır ${ }^{8}$.

\footnotetext{
${ }^{6}$ Roma dònemi sikkeleri için bkz., G.F.Hill, Catalogue of the Greek Coins in British Museum-Lycia, Pamphylia and Pisidia, London 1900.; H. Von Aulock, Sylloge Nummorum Graecorum Deutchland-Pamphylien, Berlin 1965.; E. Levante, Sylloge Nummorum Graecorum France 3-Pamphylie, Pisidie, Lycaonie, Galatie, Paris 1994 ve M. Arslan, "Anadolu Medeniyetleri Müzesi Koleksiyonundaki Pamphylia Bölgesi Şehir Sikkeleri." Anadolu MedeniyetleriMüzesi1997 Yillğı. Ankara 1998.: 15-51.

${ }^{7}$ M. Arslan s C. Lightfoot, Antik Sikke Defineleri. Ankara 1999. ve M. Arslan-C. Lightfoot, Greek Coins Hoards in Turkey. Ankara 1999. Türkçe ve İngilizce iki ayn kitapta, "Side 1963 Definesi", Side 1994 Definesi" ve "Karakuyu Definesi" adlarıyla yayımlamıştuk.

${ }^{8}$ F. Büyükyörük, "Side Tetradrahmi Definesi 1997". Türk Arkeoloji ve Etnografya Dergisi, say: 2. Ankara 2001: 95-110.
} 
İçerisinde Side tetradrahmilerinin bulunduğu defineler':

1-Batu Anadolu (Asia Minor)- Buluntu yeri saptanamayan 4 define

2-Pergamon Definesi -Mysia

3-Sardes Definesi -Lydia

4-Mektepini Definesi - Phrygia

5-Ayazin Definesi - Phrygia

6-Konya Definesi - Lykaonia

7-Antiochia Definesi - Syria - Seleukeia ad Pieria

8-Diyarbakır Definesi - Doğu Anadolu - Mesopotamia

9-Kosseir Definesi - Syria

10-Aleppo Definesi - Syria

11-Latakia Definesi - Syria

12-Laodikeia Definesi - Syria

13-Ma'arret en Numan Definesi - Syria

14-Khan Sheikhun Definesi - Syria

15-Syria Bölgesinden buluntu yeri saptanamayan 2 adet define

16-Tel Kotchek Definesi - Mesopotamia

17-Babylon Definesi - Babylonia

18-Susa definesi - İran

19-Misır'dan bir define

Sadece Side tetradrahmilerinden oluşan defineler:

1-) 1963 Yilı Side Definesi - Pamphylia - Antalya Müzesi (85 adet)

2-) 1994 Yilı Side Definesi - Pamphylia - Antalya Müzesi (15)

3-) Karakuyu Side Definesi 1992 - Pamphylia - Antalya Müzesi (269)

4-) Side Tetradrahmi Definesi 1997-Pamphylia-Antalya Müzesi (53)

5-) Yeșilova-Çeltek Side Definesi - Pisidia - Burdur Müzesi (33)

"Bkz., Harita la ve $1 b$. 
6-) 1995 Yilı Hocalar - Side Definesi - Phrygia - Uşak Müzesi (19)

7-) 1986 Yilı Side - Saarland Üniversitesi - Almanya (342 adet)

8-) 1987 Yllı Side - Saarland Üniversitesi - Almanya (218 adet)

9-) 1986 Yilı Side - Frankfurt Üniversitesi - Almanya (127 adet)

10-) Münih - Almanya özel bir koleksiyonda (127 adet)

11-) Münih - Almanya 1967 ylında müzayededen satılmış (25 adet)

Yukarıda listede görüleceği üzere, en çok Side tetradrahmi definesi, Almanya'da ve Antalya Müzesinde bulunmaktadır. Antalya Müzesinde 4 ayrı define bulunmaktadır. Dört defineden biri erken tarihli basımlardandır ${ }^{10}$. Diğer üç define geç basımlardan olan $\mathrm{K} \Lambda \mathrm{E}-\mathrm{YX}(=$ Kleuch...$)$ magistrat isimlidir. Bu üç geç basımlı defineler tarafımızdan yayımlanmıștır ${ }^{11}$. Almanya'da ise biri yayımlanmış ${ }^{12}$, dördü henüz yayımlanmamış 5 adet definenin varlığını bilmekteyiz ${ }^{13}$.

Hocalar Definesindeki damgalar (kontrmarklar): Bu defineyi daha ilginç kılan olay, define sikkelerinin çoğunluğu üzerinde görülen kontrmarklardır ${ }^{14}$. Sikkeler üzerine sonradan vurulan ve çok çeşitli tip arz eden bu kontrmarklar sikkeyi tedavüle süren devlet tarafindan basturilmaktadır. Bu damgaların amacı birkaç şekilde olabilir. Bunlardan en geçerli olanı, bir sikkeye yeni ve enflasyona göre daha yüksek bir değer vermek için yapılandır. Bir başka nedeni ise, yabancı bir devletin parasını tanıdığını ve kendi tetradrahmileri ile eşit saydığının bir delilidir. Hocalar Side Definesinde 10 adet sikke üzerinde kontrmarklar görülmektedir (bkz., kat. no. 1, 3, 5, 7, 8, 14, $15,16,17$ ve 18). Bunların 9 adeti ön yüzde olmasına karşın, yalnızca bir sikkede kontrmark arka yüze (bkz., kat. no. 1) basılmıștır. Kontrmarların büyük çoğunluğu (8 adet) Bergama Krallığına ait olan ve "kistophorik kontrmarklar" diye tanımlanan kılıfı içinde yay motiflidir. İki adet sikkede ise, biri arka yüzde (no. 1) biri ön yüzde (no. 14) olmak üzere "Suriye Krallı̆ımın" arması

${ }^{10}$ Büyükyörük 2001, bkz., a.g.y.

${ }^{11}$ Arslan-Lightfoot 1999a ve 1999b, bkz., a.g.y.

${ }^{12}$ Yayımlanmış Side definesi için bkz., W. Leschhorn, "Ein Shatzfund sidetischer Münzen", SIDE Münzprägung. Inschriften und Geschichte einer antiken stadt in der Turkei (yazarlar: $P$. R. Franke ve arkadaşları), Saarbrücken 1988: s. 23-42.

${ }^{13} \mathrm{Bkz}$., Leschhorn 1989, a.g.y. s. 23 de bu definelerden bahsetmektedir.

${ }^{14}$ Kontrmarklar için bkz., G. Le Rider, "Contremarques et surfrappes dans l'antiquité grecques", NAPM Nancy-Louvain 1975: 27-56. 
olan gemi çıpa'sı görülmektedir. Yuvarlak şekilli kistophorik kontrmarklar'ın içinde yay kılıfı ile birlikte basılmış oldukları Bergama Krallığı şehirlerini işaret eden, şehrin isminin ilk üç veya dört harfi okunmaktadır. Bunlar, ПЕP (=Pergamon), ЕФЕ (=Ephesos), АПА (=Apameia), АПО $\Lambda$ (=Apollonia),

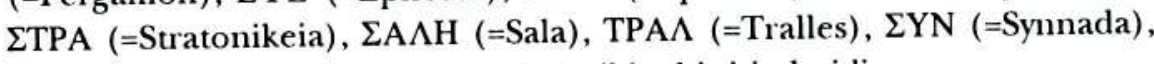
$\Lambda \mathrm{AO}$ (=Laodikeia) ve $\Theta Y A$ (=Tyatira) gibi şehir isimleridir.

Kistophorik ve Selevkos kontrmarklı sikkeler: Kistophorik sikkeler, M.Ö. 2. yüzyılın 1. çeyreğinde Bergama Krallarından Eumenes II (M.Ö. 197-167) tarafından bastırılan yeni bir sikke tipidir. Bu sikkeler 12.50 gram ağırlığıyla, 17.20 gram ağırlıktaki Attika standartındaki paraların satın alma güçüne eşit tutulmuştur. Bergama Krallığının bu yeni gümüs tetradrahmisinin ön yüzünde sarınaşık yaprağı ve meyvelerinden yapılmış bir çelenk içinde, kapağı aralanmış sihirli sepetten (Kista Mystika) kıvrılarak bir yılan çıkmakta, arka yüzünde, süslü bir yay torbasının (sadak) iki yanında başları dik ve karşılıklı, kuyrukları ise birbirine dolanmış iki yılan tasviri bulunmaktadır. Bu sikkelerin sol boşluğunda basıldığı şehrin kısaltılmıș ilk üç veya dört harfi ile monogramı yer almaktadır. Sağ boşlukta, üstte yılanın bașları arasında veya sol boşlukta basıldıkları şehre göre değişen semboller ve monoğramlar görülür. Bu sikkelerdeki basılan şehri gösteren, şehrin adının ilk üç veya dört harfi, buradaki definedeki sikkelerde aynen karşımıza çıkmaktadır.

Sikkelerin ön yüzündeki "Sihirli Sepet" tasvirinden dolayı bu gümüş sikkelere "Kistophorik" sikkeler denilmiștir. Bu sikkeler, başta krallığın merkezi Pergamon olmak üzere, 16 kadar Bergama Krallı̆̆ı hakimiyetindeki Batı Anadolu kentlerinde basturılmışur. Bu șehirler şunlardır: 1-) Pergamon-Mysia, 2-) Adramytion-Mysia, 3-) Ephesos-Ionia, 4-) Phokaia-Ionia, 5-) SmyrnaIonia, 6-) Apollonis-Lydia, 7-) Sala-Lydia, 8-) Sardes-Lydia, 9-) Nysa-Lydia, 10) Stratonikeia ad Kaikos-Lydia, 11-) Thyateria-Lydia, 12-) Tralles-Lydia, 13-) Apameia-Phrygia, 14-) Hierapolis-Phrygia, 15-) Laodikeia-Phrygia, 16-) Synnada-Phrygia.

Yukarıda isimlerini vermiş olduğumuz kistophorik sikke basan 16 kent, Mysia, Ionia ve Phrygia olmak üzere üç ayrı bölgede bulunmaktadır ${ }^{15}$. Kistophor'un resmi değeri Attika tetradrahmisine eșdeğerde olup, ancak

${ }^{15}$ Kistophor sikkeleri için bkz., F. S. Kleiner and S. P. Noe, The Early Cistophoric Coinage. Numismatic Studies No. 14, New-York 1977. s. 10-18.; M. Tevfik Göktürk, "Bir Grup Erken Kistophorik Sikke". Anadolu Medeniyetleri Müzesi 1991 Yllığı, Ankara 1992: s. 101-119. 
ağırlığı yaklaşık \% 25 daha azdı. Bu kesinti ile kraliyet hazinesi büyük gümüş tasarrufu yapıyor ve kazanç sağlıyordu. Fakat o zaman Batı Anadolu'nun büyük bir kısmını kapsayan Bergama Krallı̆̆ındaki bu sikke reformu, sikkelerin basıldıkları şehirlerin atölyelerinde bu yeni paranın büyük miktarlarda basılmasına yetmiyordu. Bu nedenle kısa bir süre için yabancı sikkelerin dolaşımına izin verilmiştir. Bu yabancı sikkeler, krali damga olan yay torbası ve basıldıkları şehrin harflerini taşıyan bir motifle damgalanıyordu (kontrmarklanıyordu). İşte bu kistophorik kontrmarklar resmi makamlarca yabancı sikkeler üzerine uygulanmışur ${ }^{16}$. Çünkü baskı işlemi teorik olarak aynıdır. Kistophorik damgalar ${ }^{17}$ genellikle ön yüz resmi üzerine basılmışlardır. Yuvarlak kontrmark (damga) çukuru içine kılıfı içerisinde yay ve ilgili şehrin baş harfleri olan motif basılmaktaydı. U̇şak Müzesindeki Hocalar Definesinde 10 adet kontrmark (8'i kistophorik 2'si Suriye krallığına ait) vardır. 8 adet Kistophorik damgadan 5 'inin Bergama Krallığı hakimiyetindeki şehirlerden olduğu tespit edilmiştir. Bir sikke üzerindeki damganın hangi şehre ait olduğu (bkz., kat. no. 7) tespit edilememiştir. Ayrıca bir sik-

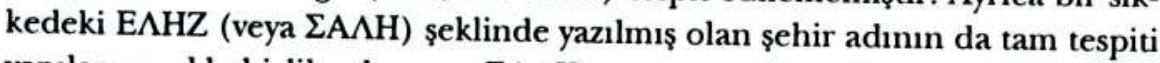
yapilamamakla birlikte bunun $\Sigma \mathrm{A} \Lambda \mathrm{H}$ (= SALE) diye okumamiz halinde bu sikkenin (bkz., kat. no. 3) Sala-Lydia kentinde basılmış olabileceğini düşünüyoruz. Definede tespit etmiş olduğumuz kistophorik damgalı 5 şehir şunlardır:

1-) ПЕР (= Pergamon-Mysia, kat. no. 18), 2-) АПА (= Apameia-Phrygia, kat. no. 17), 3-) $\Lambda \mathrm{AO}$ (= Laodikeia-Phrygia, kat. no. 5 ve 16), 4-) $\Sigma \mathrm{A} \Lambda \mathrm{H}(=$ Sala-Lydia, kat. no. 3), 5-) $\Sigma Y N$ (= Synnada-Phrygia, kat. no. 8 ve 15).

Kistophorik damgalan basan 5 şehrin tümü de, kendi kistophor sikkelerini basmış olan Bergama Krallığı şehirleridir. Bunlardan 7 numaralı sikkedeki şehrin ismi okunamamaktadır. 6 ve 16 numaralı sikkelerdeki şehir adı çok net görülmemekle beraber, Laodikeia-Phrygia olarak okumayı önermekteyiz. 8 ve 15 numaralı iki sikkenin birinci harfi tam görülmüyor, diğer iki harfin, YN şeklinde çok iyi okunmasıyla bu darphanenin, SynnadaPhrygia olması gerekir. 17 numaralı sikke üzerinde, AПА (= Apameia) ve 18

${ }^{16} \mathrm{~W}$. Leschhorn, "Ein Shatzfund sidetischer Münzen", SIDE Münzprāgung, Inschriften und Geschichte einer antiken stadt in der Turkei (yazarlar: P. R. Franke ve arkadașları), Sa-
arbrücken 1988: s. 23-42.

${ }^{17}$ Kistophorik kontrmarklar için bkz., R. Bauslagh, "Cistophoric countermarks and the monetery system of Eumenes II", NC 150, London 1990: s. 39-65. 
numaralı sikeninde, ПЕP (= Pergamon) olarak çok iyi okunduklarını burada belirtmeliyiz.

Ayrıca bu definede 2 adet sikke, Selevkos (Suriye Krallığı) kontrmarkı olarak tanımlanan gemi çıpası ile damgalanmıştur. Çıpalı kontrmarklar, Selevkos Krahı Antiochos IV (M.Ö. 175-164) tarafindan, 173-171 yılları arasında yapmış olduğu bir dizi para reformu sonucunda ortaya çıkmıștır. Bu para reformu sırasında krallığının nüfus bölgelerinde çok tutulan ve dolaşımda olan Side Tetradrahmilerini, krali sembol olan "gemi çıpası" motifi ile damgalayarak dolaşıma sürmüşlerdir.

Böylece definemizin 1 ve 14 numaralı sikkeleri üzerine basılmış olan dikdörtgen çukur içindeki gemi çıpası motifinin M.Ö. 173-171 aralığından bir tarihten olduğu kesindir. Kataloğumuzun 1 numarasında, gemi çıpası sikkenin arka yüzüne, 14 numaralıdaki ise ön yüze vurulmuştur.

Birçok araşturmacı kistophorik kontrmarkların, çıpalı kontrmarklardan daha önce vurulduklarını söylemektedir. Kistophorik damgaların ortaya çıkması, Bergama Kralı Eumenes II (197-167) zamanına, çıpalı damgaların ortaya çıkması da Antiochos IV (175-164) dönemine tarihlenmektedir. Bu durumda, kistophorik kontrmarkların, çıpalı kontrmarklardan, daha önceki bir tarihte vurulmuş olması gerekmektedir. Bu nedenle daha önceleri söylendiği üzere ${ }^{18}$, kistophor sikkelerinin M.Ö. 166 yılında değil, M.Ö. 173 yılından önceki bir tarihte basılmaya başlandığı daha mantıklı görülmektedir ${ }^{19}$. Otto Mфrkholm'a göre kistophorlar, 179-172 yılları arasında bir tarihte basılmışlardır ${ }^{20}$. Henri Seyrig, kistophorik kontrmarkların ilk kez 188 yılında, Apameia Barış Antlaşmasının akabinde ve çıpalıların ise, 171 yılında basılmış olabileceğini söylemektedir. Mфrkholm bu durumda Seyrig'ten 10 yll daha geç tarih önermektedir.

Yukarıda Side Tetradrahmilerinin bulunduğu definelerin bir listesini vermiştik. Burada görüleceği üzere bu gümüş sikkelerin ne kadar geniş bir dolaşımı olduğu bu listede görülmektedir. Bu geniş dolaşım, Side'nin ticari ilişkilerine ve Side limanımın Doğu Akdeniz'deki konumuna bağlanmalıdır. Çünkü, Side tüm Ege Denizi'ne komşu bölgeler ile tüm Orta Anadolu, Güney Doğu, Suriye ve Mısır ile ticari ilişkileri olan önemli bir liman ken-

\footnotetext{
${ }^{18}$ Kleiner-Noe 1977, bkz., a.g.y. s. 12.

1' Bkz., Leschhorn 1989, a.g.e., s. 40.

${ }^{20} \mathrm{Bkz}$., O. MHrkholm, "Some Reflection on the Production and Use of Coinage in Ancient Greece", Historia 31, 1982: s. 290-305.
} 
tiydi. Köle ticareti dışında tüm gıda maddeleri ve lüks tüketim malzemelerinin de Side Limanı'nda paketlendiğini bilmekteyiz. Bu mallar için, yurtdıșında genellikle Side tetradrahmisi ile ödeme yapılmaktaydı. Malların büyük bir kısmı Pamphylia'da kalmayıp, satılmaya devam ederdi. Bunlar için ödenen paralar da Side şehrine akardı. Yabancı paraların eritilip yeniden Side sikkeleri olarak basılmasımı şehrin bir kanun ile gerçekleștirdiğini söyleyenlerin düşüncesi doğrudur. Aksi takdirde, bu büyük gümüş miktarı başka türlü açıklanamaz. Henrig Seyrig'in de tahmin ettiği gibi, bizde Side'de bir para endüstrisinin varlığını ve sikke ihracat ile kâr amaçlandığını kabul etmekteyiz.

Biz Side tetradrahmilerinin tarihlendirilmesi ve gruplandırılmasını aşağıda vermiș olduğumuz Leschhorn listesine göre yapmaktayız ${ }^{21}$.

Hellenistik Side Tetradrahmilerinin kronoloji ve gruplandırma listesi:

\section{M.Ö. 205-200}

1. $\mathrm{A} \Phi$

2. $\mathrm{A} \Theta$

3. $P$ Yildırım demeti

4. $\mathbb{N}$ Yildırım demeti

5. $\mathbb{N}$

6. $\Delta \mathrm{I}$

7. $\triangle \mathrm{IO}$

8. $\triangle \mathrm{IO} \triangle$

9. $A$ Yildırım demeti

10. AP Celenk

11. AP Miğfer

12. AP
M.Ö. 200-190

13. 因

14. $\Sigma-T$

15. $\mathrm{X}$

16. $\mathrm{I} \mathrm{H}$

17. ए-H

18. 正-H

19. CT

20. $\triangle \mathrm{E}$

21. $\Delta \mathrm{E}$

22. $\triangle \mathrm{EI}$

23. $\triangle \mathrm{EI}-\mathrm{N}$

24. $\triangle$ EI-NO

25. $\Delta \mathrm{H}$

26. $\Delta \mathrm{H}-\mathrm{M}$

27. A

28. A-K

29. XPY

${ }^{21} \mathrm{Bu}$ liste değerli meslektaşım Leschhorn tarafından yapılmışur. Kendisine bu yayına katkısından dolayı şükranlarımı arz ederim. 


\section{Sonuç ve Değerlendirmeler:}

Uşak Müzesi'ndeki bu Side Tetradrahmi definesi, bugüne kadar ele geçmiş ve yayınlanmış erken basımlı defineler içinde en fazla yıpranmış olanıdır. Bu nedenle sikkelerin ağırlıkları, olması gereken (17.20gr.) ağırlıklarından daha düşüktür. En ağır sikke, 16.72 gram (no. 18) ve en hafif sikke, 15.55 gramdır (no. 2). Definenin 14 sikkesi, 16.00 gramın üzerinde, 5 sikkesi de 15.00 gram ile 16.00 gram arasındadır. Define sikkelerinin ortalama ağırı̆ı̆ı 16.22 gramdır. Definenin toplam ağırlığı ise, 3 kilo çekmektedir.

\section{Kalpp ilişkileri:}

Hocalar Definesinde, 19 sikke bulunmakta ve her bir sikke farklı kalıplardan üretilmiştir. Side tetradrahmileri üzerine çok geniş bir araşurma yapmış ve yukarıdaki kronoloji listesini hazırlamıs olan Leschhorn, Side sikkeleri üzerinde ismi okunan 33 yetkili memur (magistrat) ismi belirlemiştir. Bunlardan 29 adeti ilk iki seri üretimleri (M.Ö. 205-190) üzerinde okunmaktadır. Son iki serinin basımlarında (M.Ö. 188-36) sadece, $\mathrm{K} \Lambda-\mathrm{E}, \mathrm{K} \Lambda \mathrm{E}-\mathrm{EY}$ veya $\mathrm{K} \wedge \mathrm{E}-\mathrm{YX}$ diye okunan, belki aynı kişiye ait üç değişik okunuşlu isimleri görmekteyiz.

Definemizde, 14 farklı magistrat ismi ve 19 farklı arka yüz kalıbı bulunmaktadır. Sadece, katalogumuzun bir numaralı ile iki numaralı sikkelerinin, ön yüzlerinin aynı kalıptan üretilmiş olması çok muhtemel görülmektedir.

Definede aynı magistrat isimlerinden dört çift sikke bulunmaktadır. Fakat bunlardan hiçbiri aynı kalıp üretimleri değildir. Örneğin, 1 ve 2,8 ve 10 , 15 ve 16,17 ve 18 numaralı sekiz sikkemiz, aynı olan dört magistrat ismini taşımalarına karşılık, her biri farklı kalıptan basılmışlardır. Bunların farklı oldukları, aynı magistrat isimli sikkelerin, resimlerinin detaylı incelenmesi sonucu anlaşılmaktadır. Bu farklılığı görmek için, öncelikle arka yüzdeki, nar meyvesinin şekli ve sapının yönü kıstas olarak seçilmelidir. Ayrıca narın dışında magistrat adının sikke boşluğunun neresinde olduğu ve Nike figürüne olan yakınlığı ve uzaklığı da başka bir saptamadır. Yine ayrıca bazı örneklerde görülen magistrat isimlerinin ve sembollerin aynı olmasına karşıllk, aynı olan iki sembolden birinin sikke boşluğuna farklı yerleştirilmiş olduğu da görülecektir. Bunun için 1. ve 2. numarah sikkelerimizde görülen yıldırım demeti sembolü iyi bir örnek teşkil etmektedir. Birinci sikkede, yıldırım demeti nar ile Nike arasında dik olarak daha yukarda ve Nike'nin 
beli hizasındadır. İkinci sikkede ise, daha aşağıya ve Nike'nin ayakları önüne yerleştirilmiştir.

Afyon İli, Sandıklı İlçesi, Hocalar Nahiyesi, Dolay Höyükte (Diocleia antik kenti) 1995 yılında bulunan bu kontrmarklı Side Definesi, Anadolu'nın Geç Helenistik tarihi ve nümizmatik bilimi için çok önemli bir belgedir.

Side tetradrahmilerinin erken tarihli basımlarından oluşan bu definedeki sikkelerin 10 adeti üzerinde ikinci kullanımlarında vurulmuş kontrmarklar (damgalar) vardır. Bunlarda definenin başka bir devlet tarafindan tekrardan tedavüle sokularak kullanılmış olduğuna işaret eder. Bu damgaların 8 adeti Bergama Krallığının resmi işareti olan "yay kılıfı" motifidir. Kılıfı içinde yay ve basıldığı şehrin isim kısaltmaları olan bu kontrmarklar "kistophorik kontrmarklar" olarak isimlendirilmişlerdir. 2 adet sikke ise, Selevkos Krallığının işareti olan "gemi çıpası" motifli kontrmarklıdır.

Side tetradrahmi definelerinin erken tarihli basımlılarının büyük çoğunluğu üzerinde bu iki Helenistik Krallığın işareti olan kontrmarklar görülür. Çünkü M.Ö. 190 yıllarına kadar, Batı Anadolu topraklarının küçük bir kısmına Bergama Krallığı hakim, Kuzey-Batı, Güney-Batı, Orta ve Doğu kısımlarına Suriye Krallığı hakim durumda idi. Ancak bu iki krallığın birbirleriyle olan çekişmesinde, Roma Bergama Krallı̆̆ından yana taraf olmuștur. Romalı konsül ve komutan Gnaeus Manlius Vulso, 189 yilı ilkbaharında Efesos'a gelmiş ve burada büyük bir ordu kurarak, Suriye Krallı̆ğının müttefiki olan Galatların üzerine, Ankara'ya doğru bir sefere çıkmıs ve yanına da müttefiki olan Bergama Kralı Eumenes II ve kardeşi Attalos II'yi de almışur. Galatya Seferinden büyük bir zafer ile dönen Manlius Vulso, Suriye Kralı Antiochos III'ü bir barış görüşmesine ikna etti. M.Ö. 188 yazında, tarihe Apameia Barışı olarak geçen barışın kesin koşulları belirlendiğinde, Suriye Krallığı sahip olduğu, Trakya'nın Gelibolu yarımadasından, Marmara kıyısındaki birçok kentten, Mysia, Lydia, Karia, Lykia, Phrygia, Lykaonia ve Galatia'da kendisine bağlı birçok kenti terk ederek, Torosların kuzeyinden güneye çekilmeyi kabul etmiştir. Apameia Barışı sonrasında, Anadoludaki Selevkos Krallığı hakimiyetindeki yerlerin büyük bir kısmı Bergama Krallığının mülkü olmuştur.

Side'de darp edilen bu sikkelerdeki "kistophorik kontrmarklar" 188 ylh sonrasındaki ilk yıllar içinde vurulmuş olmalıdır. Gemi çıpalı kontrmarkların da, Suriye Kralı Antiokhos'un (175-164) döneminden, yani M.Ö. 166 yıllarında vurulduğunu söylemek istiyoruz. Böylece definenin de, M.Ö. 160 yılları arasındaki bir tarihte toprağa gömülmüş olması muhtemeldir. 
Faydalı Kaynakçalar ve Kısaltmalar:

Arslan 1997

Arslan 1998

Arslan 1999a

Arslan 1999b

Arslan 2001

Arslan 2004

Atlan 1967

Atlan 1975

Büyükyörük 2001

Bauslaugh 1990

M. Arslan, "Yeşilova-Çeltek Side Tetradrahmisi 1995". ADALYA Dergisi, sayı: 2, Antalya 1997: s. 51-69.

M. Arslan, "Anadolu Medeniyetleri Müzesi Koleksiyonundaki Pamphylia Bölgesi Şehir Sikkeleri.” Anadolu Medeniyetleri Müzesi 1997 Yllığı, Ankara 1998: s. 15-51.

M. Arslan-C. Lightfoot, Antik Sikke Defineleri. Ankara 1999.

M. Arslan-C. Lightfoot, Greek Coin Hoards in Turkey. Ankara 1999.

M. Arslan, "Burdur Müzesi'ndeki Side Tetradrahmi Definesi". TTK. Belleten, Sayı: 242, LXV, Ankara Nisan 2001: s. 37-61.

M. Arslan, Galatya Krallığı ve Roma Dönemi Ankyra Sehir Sikkeleri -The Coins of Galatian Kingdom and The Roman Coinage of Ancyra in Galatia. Ankara Ticaret Odası Yayınları, Ankara 2004.

S. Atlan, Side'nin Milattan önce V. ve IV. Yüzyıl Sikkeleri üzerinde Araşturmalar-Untersuchungen über die Sidetischen Münzen des V. und IV. Jahrhunder v. Chr., TTK, Ankara 1967.

S. Atlan, "Side'de Basılan Amyntas Sikkeleri-Die Münzprägung des Amyntas in Side”. TTK. Belleten, Sayı: 39, Ankara 1975: s. 575-611.

F. Büyükyörük, "Side Tetradrahmi Definesi 1997". Türk Arkeoloji ve Etnografya Dergisi, Sayı: 2, Ankara 2001: s. 95-110.

R. Bauslaugh, "Cistophoric countermarks and the monetary system of Eumenes II", NC 150, London 1990: s. 3965.

Boehringer 1972 C. Boehringer, Zur Chronologie mittelhellenistisch Münzserien 220-160, v. Chr., Berlin 1972.

Bosch 1957 Cle. E. Bosch, Pamhpylia Tarihine Dair Tetkikler-Studien Zur Geschichte Pamphyliens. TTK. V. Seri No. 17, Ankara 1957: s. 1-48.

BMC Pamphylia G. F. Hill, Catalogue of the Greek Coins of Lycia, Pamphylia and Pisidia, London 1897. 
Göktürk 1991 M. Tevfik Göktürk, "Bir Grup Erken Kistophorik Sikke”. Anadolu Medeniyetleri Müzesi 1991 Yillığı, Ankara 1992: s. 101-119.

Kleiner-Noe 1977 F. S. Kleiner-S. P. Noe, The Early Cistophoric Coinage, Numismatic Studies No. 14, New York 1977.

Leschhorn 1989 W. Leschhorn, "Ein Shatzfund sidetischer Münzen", SIDE Münzprägung, Inschriften und Geschichte einer antiken stadt in der Turkei (yazarlar: P. R. Franke ve arkadaşları), Saarbrücken 1988: s. 23-42.

Le Rider 1975 G. Le Rider, "Contremarque et surfrappes dans L'Antiquité grecque", Numismatique antique. Problèmes et méthodes, Nancy-Louven 1975: s. 27-56.

Mфrkholm 1979 O. M $\phi$ rkholm, "Some reflection on the early cistophoric coinage", ANSMN 24, New York 1979: s. 47-61.

MHrkholm 1982c O. MHrkholm, "Some reflection on the production and use of coinage in ancient Greece", Historia 31, (1982): s. 290-305.

Mowat 1906 R. Mowat, "Trois contremarques inédites sur des tétradrachmes de Sidé", Corolla numismatica. Numismatic essays in honour of Barclay V. Head. New YorkLondon 1906: 189-207.

Seyrig 1958b H. Seyrig, "Antiquités Syriennes 67: Monnaies contremarquées en Syrie", Syrie 35, Paris 1958: s. 187-197.

Seyrig 1963 H. Seyrig, "Monnaies hellénistiques", RN 5, Paris 1963: s. 7-64.

SNG Aulock H. Von Aulock, Sylloge Nummorum Graecorum. Deutchland: Sammlung Von Aulock, Pamphylien, Berlin 1965.

SNG France 3 E. Levante, Sylloge Nummorum Graecorum. France 3: Pamphylie, Lycaonie, Galetie, Paris 1994.

SNG PfPs J. Nolle, Sylloge Nummorum Graecorum. Deutchland: Privatsammlungen, Band 4, Pamphylien, München 1992. 


\section{KATALOG}

\section{M.Ö. 205-200}

Grup 4 - Magistrat : $\quad \mathbb{N}$ ve yldınm demeti

1. Ön yüz Athena'nın miğferli başı sağa.

Arka yüz Nike sola yürüyor, sağ elinde çelenk ve sol eliyle mantosunun eteğini tutuyor; sol boşlukta, $\mathbb{N}$ ve nar, ayrıca dik şekilde yıldırım demeti sembolü, Nike'nin beli hizasında; sağ boşlukta alt kenarda, dikdörtgen çukur içinde, gemi çıpalı Selevkos kontrmarkı.

Env. No. $\quad 11963$

Ölç/Ağr /Yön $15.73 \mathrm{gr} ; 32 \mathrm{~mm}$. 12h.

Ref. $\quad$ BMC Pamphylia, no. 32 [Pl. XXVII. 4] benzer; SNG von Aulock, no. 4783.

2. Ön yüz Athena'nın miğferli başı sağa.

Arka yüz Nike sola yürüyor, sağ elinde çelenk ve sol eliyle mantosunun eteğini tutuyor; sol boşlukta, $\mathbb{N}$ ve nar, ayrıca dik şekilde yıldırım demeti sembolü, $\mathrm{Ni}$ ke'nin ayakları önünde.

Env. No. 11958

Ölç/Ağr $/$ Yön $15.55 \mathrm{gr} ; 30 \mathrm{~mm} .12 \mathrm{~h}$.

Ref. SNG von Aulock, no. 4783 benzer kalıp.

\section{Grup 6 -Magistrat : $\mathbb{N}$}

3. Ön yüz Athena'nın miğferli başı sağa; yuvarlak çukur içinde yay kılıfı ve $\mathrm{E} \Lambda \mathrm{HZ}$ (= şehir ?) yazıtlı kistophorik kontrmark.

Arka yüz Nike sola yürüyor, sağ elinde çelenk ve sol eliyle mantosunun eteğini tutuyor; solda, $\mathbb{N}$

ve nar.

Env. No. $\quad 12197$

Ölç/Ağr/Yön $16.26 \mathrm{gr} ; 32 \mathrm{~mm}$. 12h.

Ref. SNG von Aulock, no. 4781-2 benzer; SNG France 3, no. 685 çok benzer kalıp. 


\section{Grup 7 - Magistrat : $\triangle I O$}

4. Ön yüz

Athena'nın miğferli başı sağa.

Arka yüz

Nike sola yürüyor, sağ elinde çelenk ve sol eliyle

Env. No. mantosunun eteğini tutuyor; solda, $\Delta \mathrm{IO}$ ve nar.

Ölç/Ağr $/$ Yön 11955

Ref.

$15.76 \mathrm{gr} ; 31 \mathrm{~mm} .12 \mathrm{~h}$.

SNG von Aulock, no. 4790 benzer; SNG France 3, no. 685 benzer kalıp.

\section{Grup 8 - Magistrat : $\Delta$ I O $\Delta$}

5. Ön yüz

Athena'nın miğferli başı sağa; yuvarlak çukur içinde yay kılıfı ve $\Lambda \mathrm{AO}$ (= Laodikeia) yazıth kistophorik kontrmark.

Arka yüz Nike sola yürüyor, sağ elinde çelenk ve sol eliyle mantosunun eteğini tutuyor; solda, $\Delta \mathrm{IO} \Delta$ ve nar.

Env. No. $\quad 11961$

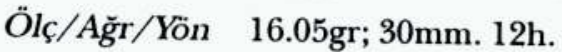

Ref. BMC Pampylia, no. 37; SNG von Aulock, no. 4788-9 benzer; SNG France 3, no. 690-1 benzer kalıp.

\section{Grup 10 - Magistrat : AP ve çelenk}

6. Ön yüz Athena'nın miğferli başı sağa.

Arka yüz Nike sola yürüyor, sağ elinde çelenk ve sol eliyle mantosunun eteğini tutuyor; solda, AR ve nar ile sembol çelenk.

Env. No. $\quad 11956$

Ölç/Ağr/Yön $16.13 \mathrm{gr} ; 31 \mathrm{~mm} .12 \mathrm{~h}$.

Ref. BMC Pampylia, no. 22 benzer; SNG von Aulock, no. 4778 benzer; SNG France 3, no. 665 çok benzer kalıp; Büyükyörük 2001, no. 7-8.

\section{Grup 15 - Magistrat : $\mathbb{Z}$}

7. Ön yüz Athena'nın miğferli başı sağa; yuvarlak çukur içinde yay kılıfı ve okunamayan şehir adı (?) olan kistophorik kontrmark. 
Arka yüz Nike sola yürüyor, sağ elinde çelenk ve sol eliyle mantosumun eteğini tutuyor; soldla, $\mathbb{X}$

Env. No. $\quad 11969$

Ölç/Ağr/Yön $15.97 \mathrm{gr} ; 30 \mathrm{~mm} .12 \mathrm{~h}$.

Ref. $\quad$ BMC Pampylia, no. 47-8; SNG von Aulock, no. 4794; Arslan 2001, no. 8 .

\section{Grup 16-Magistrat : $\quad \nabla \mathrm{H}$}

8. Ön yüz Athena'nun miğferli başı sağa; yuvarlak çukur içinde yay kılıfı ve $[\Sigma] Y N$ (= Symnada) yazıtlı kistophorik kontrmark.

Arka yüz Nike sola yürüyor, sağ elinde çelenk ve sol eliyle mantosumun eteğini tutıyor; solda, $\quad \mathbf{Z} \mathbf{H}$

Env. No. $\quad 11969$

Ölৎ/Ağr $/$ Yön $16.22 \mathrm{gr} ; 30 \mathrm{~mm} .12 \mathrm{~h}$.

Ref.

SNG France 3, no. 708-11; Büyükyörük 2001, no. 14 15; Leschhorn 1989, Tafel I, 19.

9. Ön уйі $\quad$ Athena'nın miğferli başı sağa.

Arka yüz 8 numaralı sikke gibi, ama farklı kalıp.

Env. No. $\quad 11970$

Ölç/Ağr /Yön 16.33gr; 29mm. 12h.

Ref. SNG France 3, no. 708-11;Büyükyörük 2001, no. 1416; Leschhorn 1989, Tafel I, 19.

10. Ön уӥз Athena'nun miğferli başı sağa.

Arka yüz $\quad 8$ ve 9 numaralı sikke gibi, ama farklı kalıp.

Env. No. $\quad 12198$

Ölç/Ağr/Yön $16.53 \mathrm{gr}^{\prime} ; 30 \mathrm{~mm} .12 \mathrm{~h}$.

Ref.

SNG France 3, no. 708-11; Büyükyörük 2001, no. 1416; Leschhorn 1989, Tafel I, 19. 


\section{Grup 17 -Magistrat : $\quad \mathbb{Z}-\mathbf{H}$}

11. Ön yüz Athena'nun miğferli bașı sağa.

Arka yüz Nike sola yürüyor, sağ elinde çelenk ve sol eliyle mantosunun eteğini tutuyor; solda, nar ve $\mathbb{Z}$ - H

Env. No. $\quad 11968$

Ölç/Ağr/Yön 16.48gr; $29 \mathrm{~mm}$. 12h.

Ref. SNG von Aulock, no. 4793; SNG France 3, no. 71314; Arslan 2001, no. 9; Büyükyörük 2001, no. 12.

\section{Grup 19 - Magistrat : CT}

12. Ön yüz Athena'nun miğferli bașı sağa.

Arka yüz Nike sola yürüyor, sağ elinde çelenk ve sol eliyle mantosunun eteğini tutuyor; solda, nar ve CT

Env. No. $\quad 11957$

Ölç/Ağr/Yön 16.03gr; 30mm. 12h.

Ref. BMC Pampylia, no. 50; SNG von Aulock, no. 4792.

\section{Grup 22 - Magistrat : $\triangle \mathrm{EI}$}

13. Ön yüz Athena'nın miğferli bașı sağa.

Arka yüz Nike sola yürüyor, sağ elinde çelenk ve sol eliyle mantosunun eteğini tutuyor; solda, nar ve $\Delta \mathrm{EI}$

Env. No. $\quad 11964$

Ölç/Ağr/Yön 16.30gr; 30mm. 12h.

Ref. BMC Pampylia, no. 25; SNG von Aulock, no. 4786;

SNG France 3, no. 674-676; Leschhorn 1989, Tafel

I, 10; Arslan 2001, no. 11; Büyükyörük 2001, no. 19 20.

\section{Grup 25 - Magistrat : $\Delta \mathbf{H}$}

14. Ön yüz Athena'nın miğferli başı sağa; dikdörtgen çukur içinde, gemi çıpası, Selevkos kontrmarkı. 
Arka yüz Nike sola yürüyor, sağ elinde çelenk ve sol eliyle mantosunun eteğini tutuyor; solda, nar ve $\Delta H$

Env. No. 11966

Ölç/Ağr /Yön 16.47gr; 30mm. 12h.

Ref.

Leschhorn 1989, Tafel I, 16; SNG France 3, no. 68283; Arslan 2001, no. 19-23.

\section{Grup 26 - Magistrat : $\Delta \mathrm{H}-\mathbf{M}$}

15. Ön yüz Athena'nın miğferli başı sağa; yuvarlak çukur içinde yay kılıfi ve $\Sigma$ YN (= Synnada) yazıtlı kistophorik kontrmark.

Arka yüz Nike sola yürüyor, sağ elinde çelenk ve sol eliyle mantosunun eteğini tutuyor; solda, nar ve $\Delta \mathbf{H}$; sağda, M

Env. No. $\quad 11960$

Ölç/Ağr/Yön 16.69gr; 31mm. 12h.

Ref. BMC Pampylia, no. 30; SNG France 3, no. 684; Arslan 2001, no. 24-28; Büyükyörük 2001, no. 22.

16. Ön yüz Athena'nın miğferli başı sağa; yuvarlak çukur içinde yay kılıfı ve $\Lambda \mathrm{AO}$ (= Laodikeia) yazıtlı kistophorik kontrmark.

Arka yüz 15 numaralı gibi, ama farklı kalıp.

Env. No. $\quad 11967$

Ölç/Ağr/Yön 15.96gr; 29mm. 12h.

Ref. BMC Pampylia, no. 30; SNG France 3, no. 684; Arslan 2001, no. 24-28; Büyükyörük 2001, no. 22.

\section{Grup 28 - Magistrat : A - K}

17. Ön yüz Athena'nın miğferli başı sağa; yuvarlak çukur içinde yay kılıfı ve AПA (= Apameia) yazıtlı kistophorik kontrmark. 
Arka yüz Nike sola yürüyor, sağ elinde çelenk ve sol eliyle mantosunun eteğini tutuyor; solda, nar ve A ; sağda, K

Env. No. 11962

Ölç/Ağr/Yön 16.62gr; 30mm. 12h.

Ref.

SNG von Aulock, no. 4780; SNG France 3, no. 66061; Leschhorn 1989, Tafel I, 7; Arslan 2001, no. 29; Büyükyörük 2001, no. 23.

18. Ön yӥz

Athena'nın miğferli başı sağa; yuvarlak çukur içinde yay kılıfı ve ПIEP (= Pergamon) yazıtlı kistophorik kontrmark.

Arka yӥz 17 numaralı sikke gibi, ama kalıp farklı.

Env. No. 11959

Ölç/Ağr/Yön $16.72 \mathrm{gr} ; 31 \mathrm{~mm} .12 \mathrm{~h}$.

Ref. SNG von Aulock, no. 4780; SNG France 3, no. 66061; Leschhorn 1989, Tafel I, 7; Arslan 2001, no. 29; Büyükyörük 2001, no. 23.

\section{Grup 29 - Magistrat : XPY}

19. Ön yüz Athena'nın miğferli başı sağa.

Arka yüz Nike sola yürüyor, sağ elinde çelenk ve sol eliyle mantosunun eteğini tutuyor; solda, nar ve XPY

Env. No. $\quad 11962$

Ölç/Ağr/Yön $16.40 \mathrm{gr} ; 31 \mathrm{~mm} .12 \mathrm{~h}$.

Ref. $\quad$ Leschhorn 1989, Tafel I, 20; SNG France 3, no. 702; Arslan 2001, no. 30-33; Büyükyörük 2001, no. 24. 
Melih Arslan

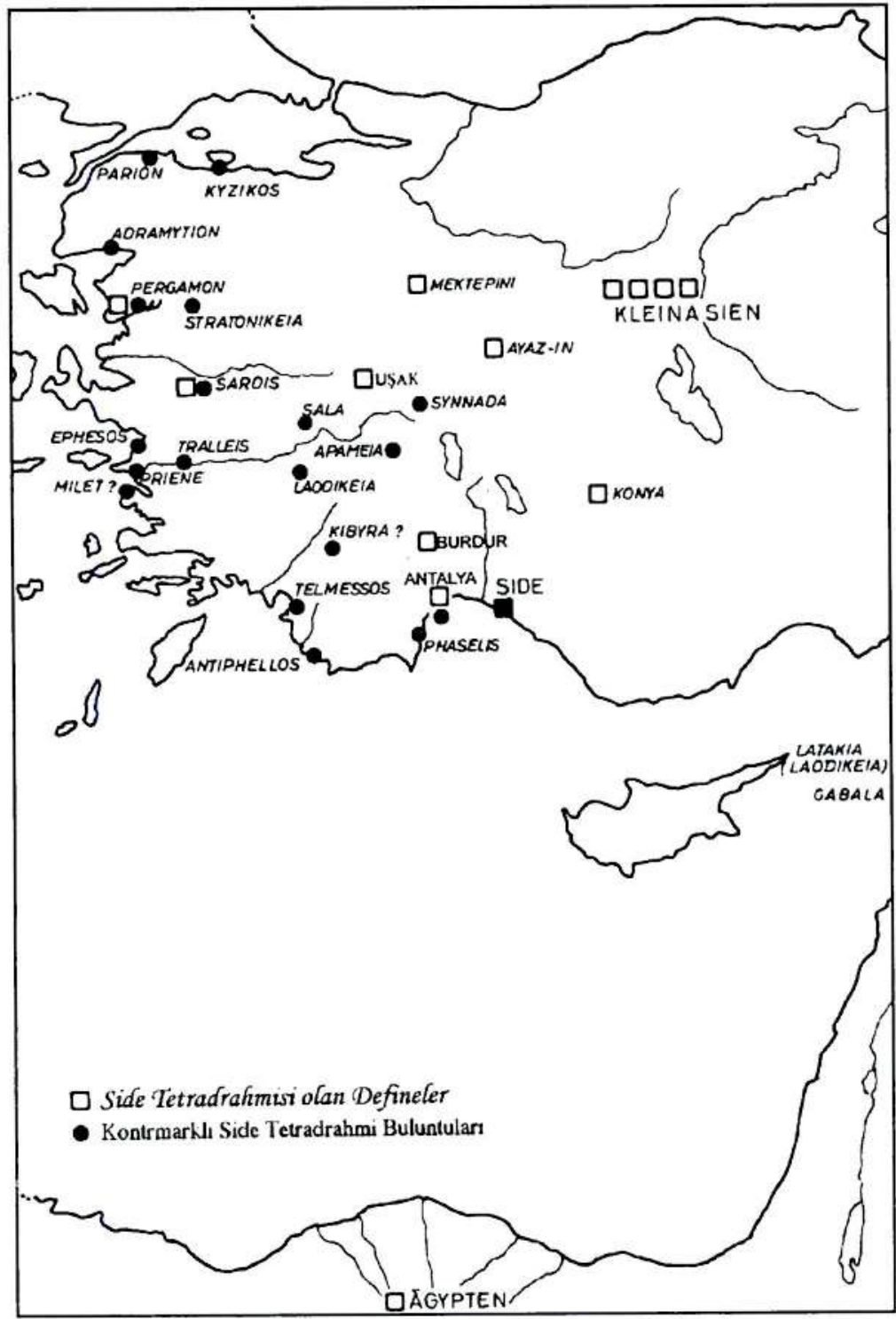

Harita la - Side Tetradrahmilerinin Anadolu ve Mısır içerisindeki dağılımları 
Melih Arslan

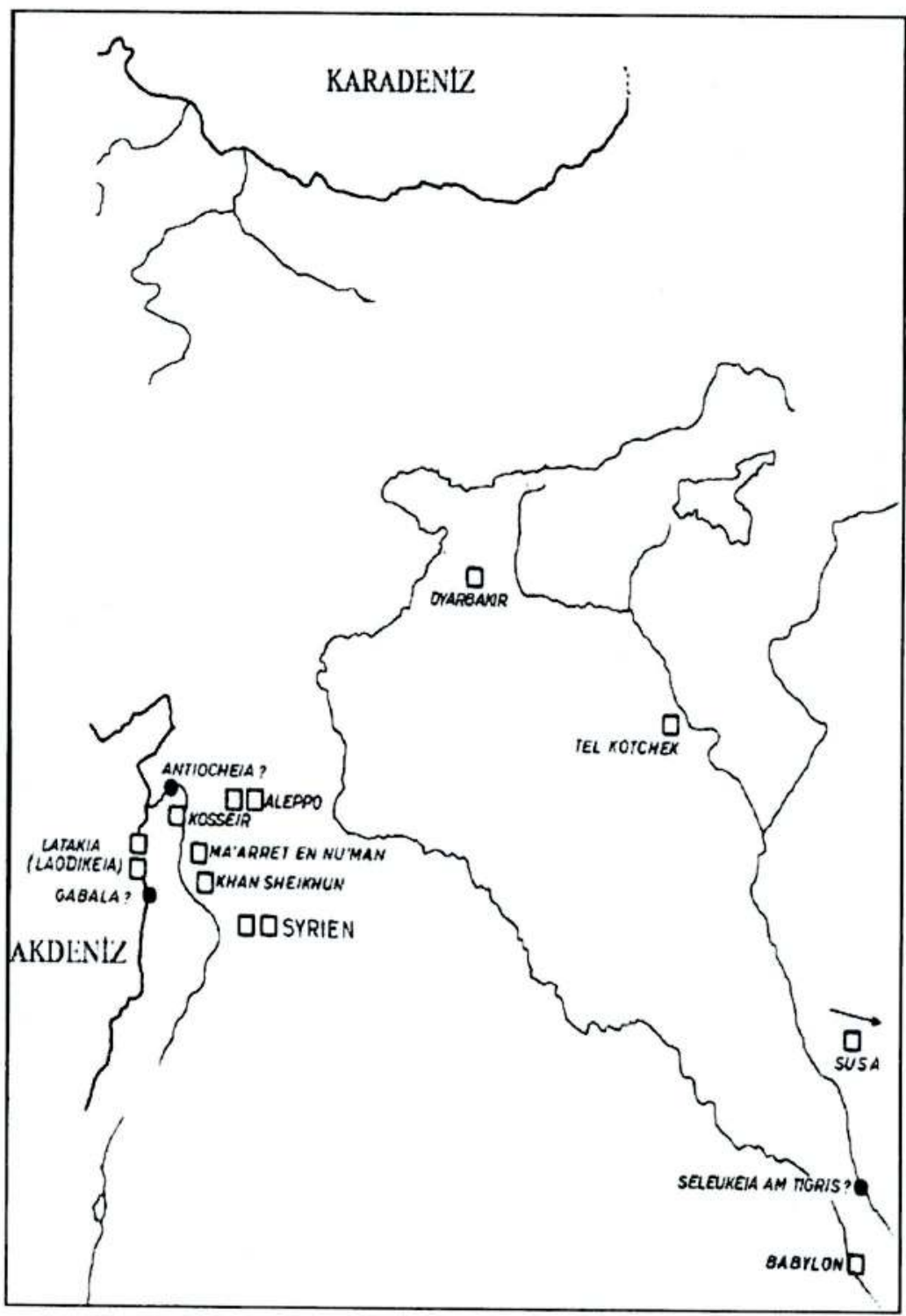

Harita Ib - Side Tedradrahmilerin Mesopotamia, Syria, Babylonia ve Persia (İran) içindeki dağılımı 
Melih Arslan

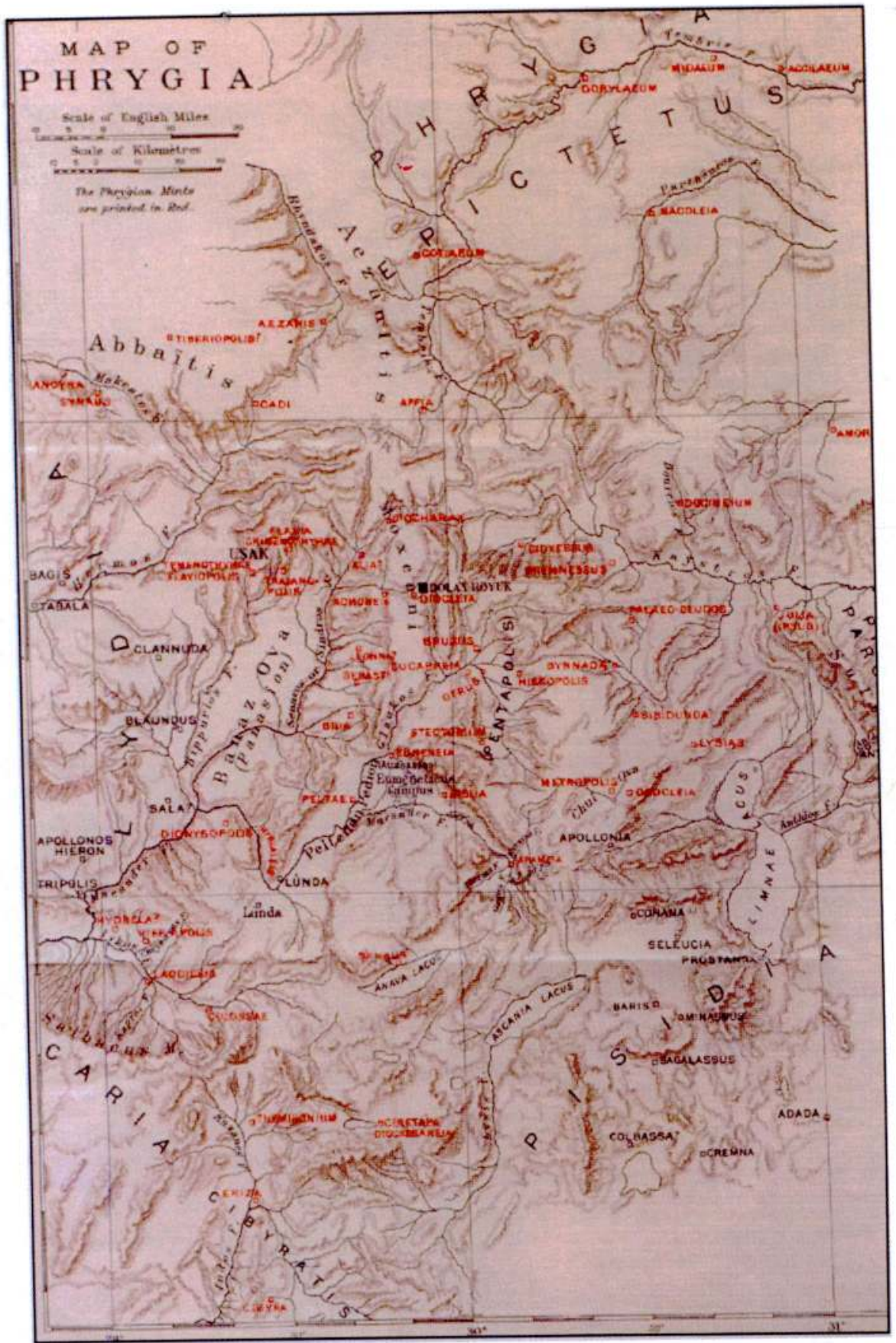

Harita 2 - Ușak Müzesi, Hocalar Definesinin buluntu yeri için, bkz., yukarıda: Dolay Höyük - Diocleia Antik Kenti 
Melih Arslan

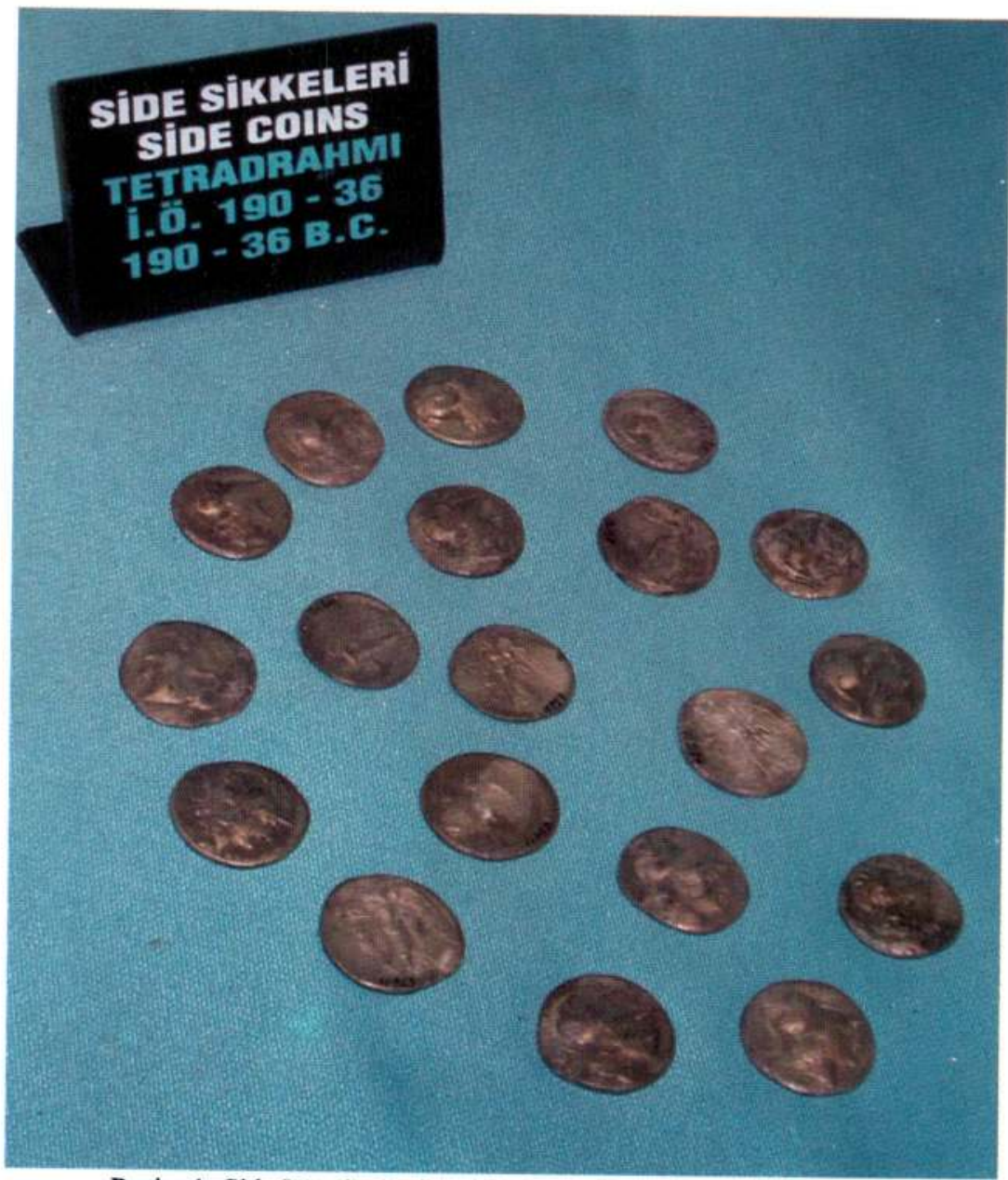

Resim 1- Side Hocalar Definesi'nin Uşak Müzesi'ndeki Sergilenişi. 

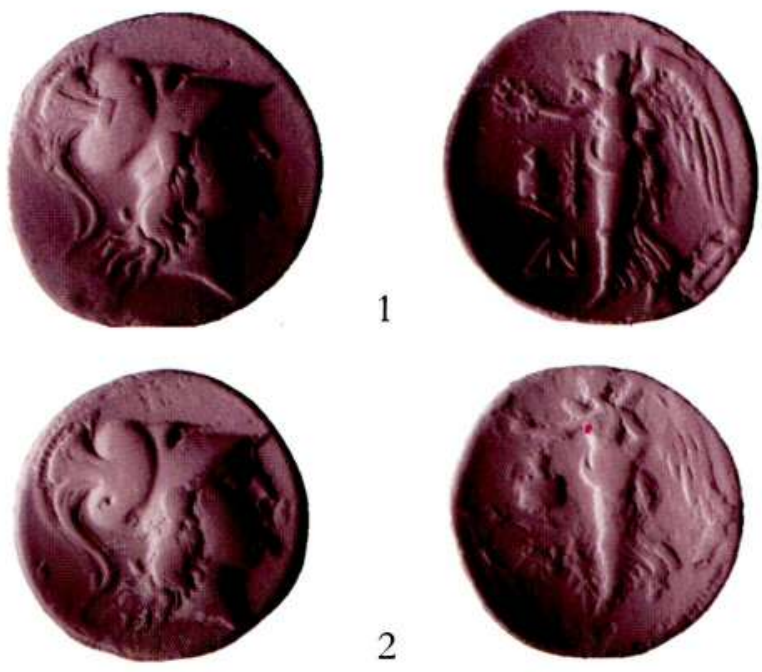

2
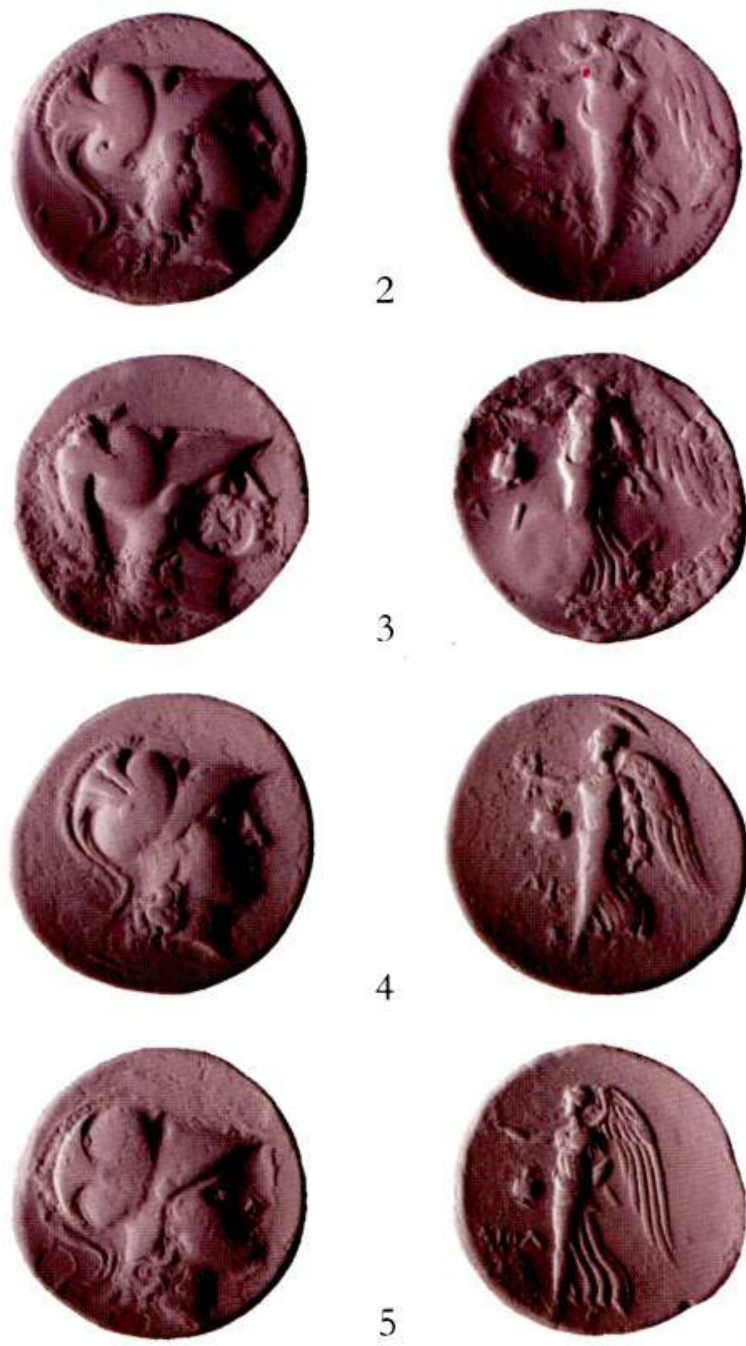

4
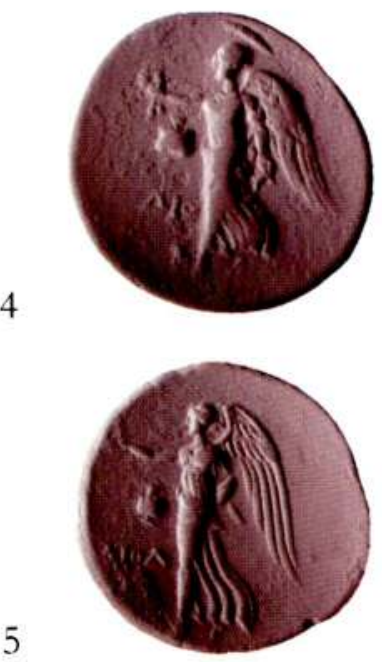


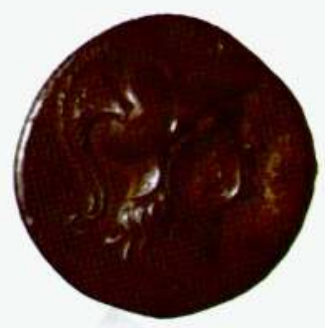

6
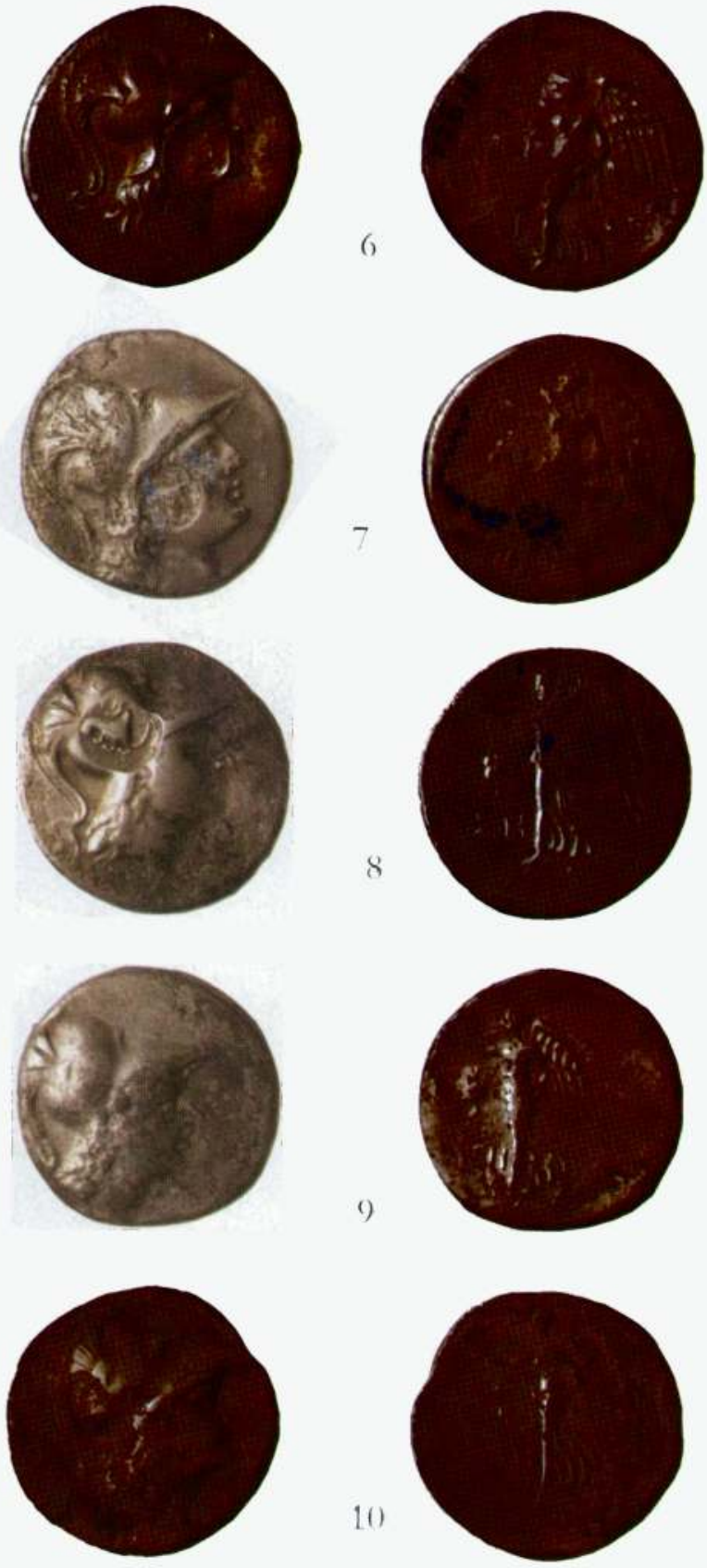


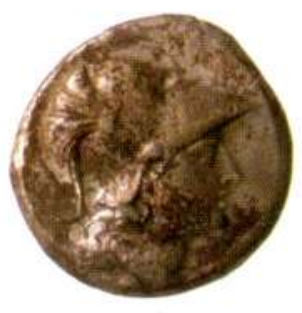

11
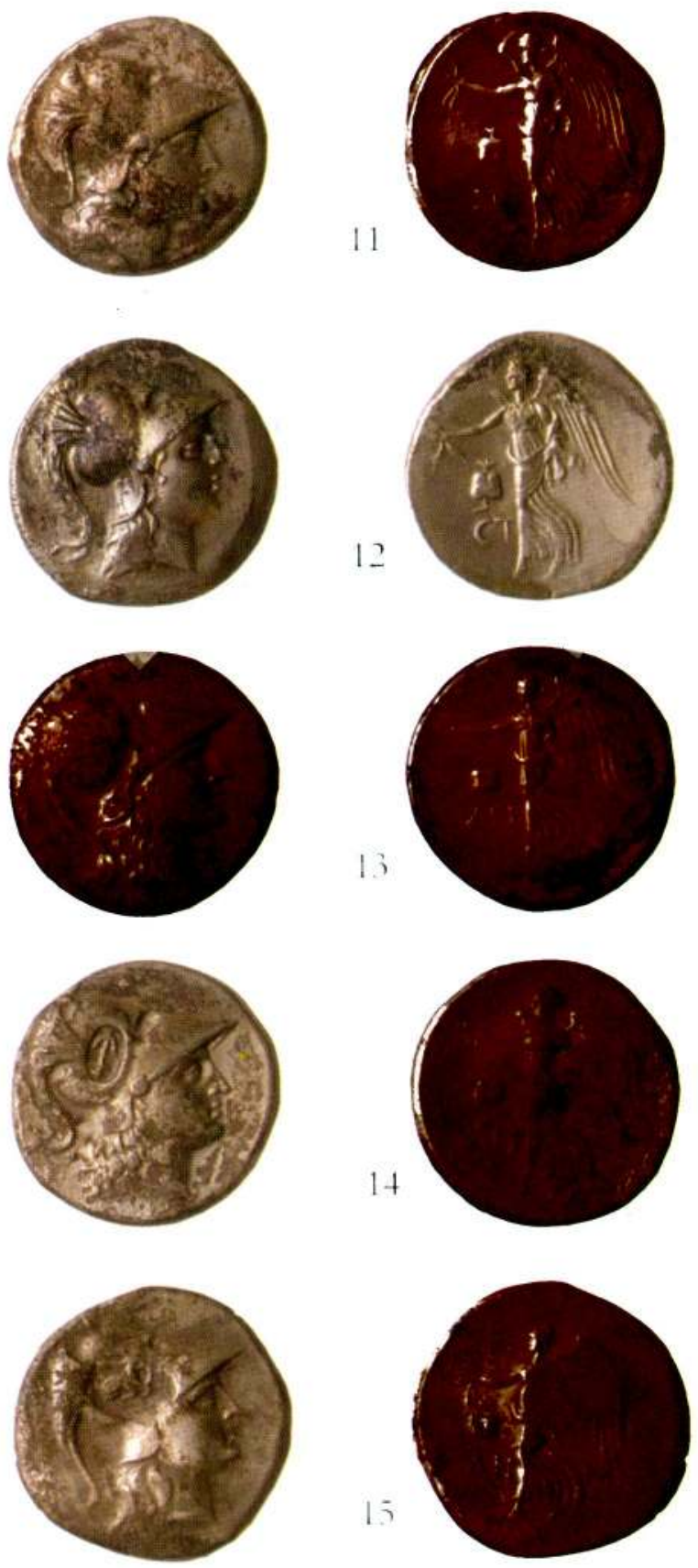
Melih Arslan

Levha IVa
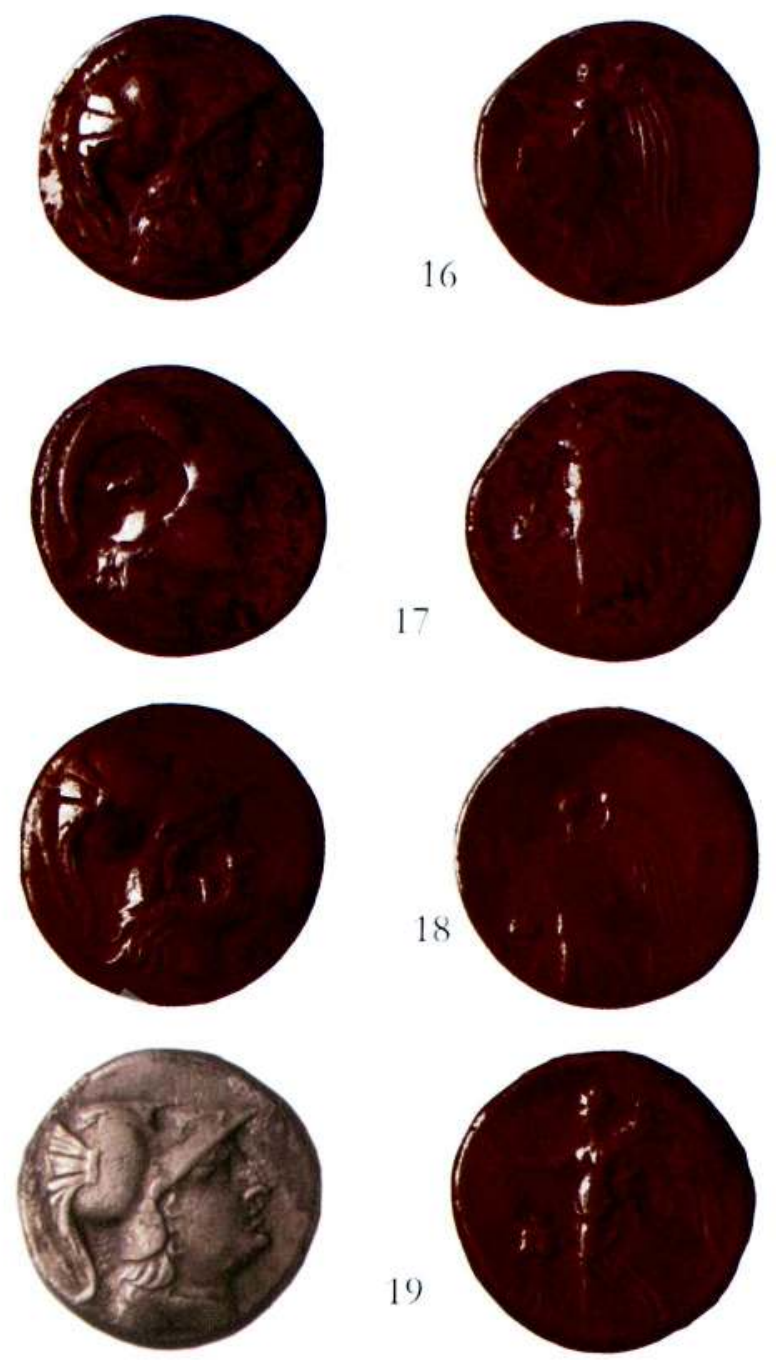

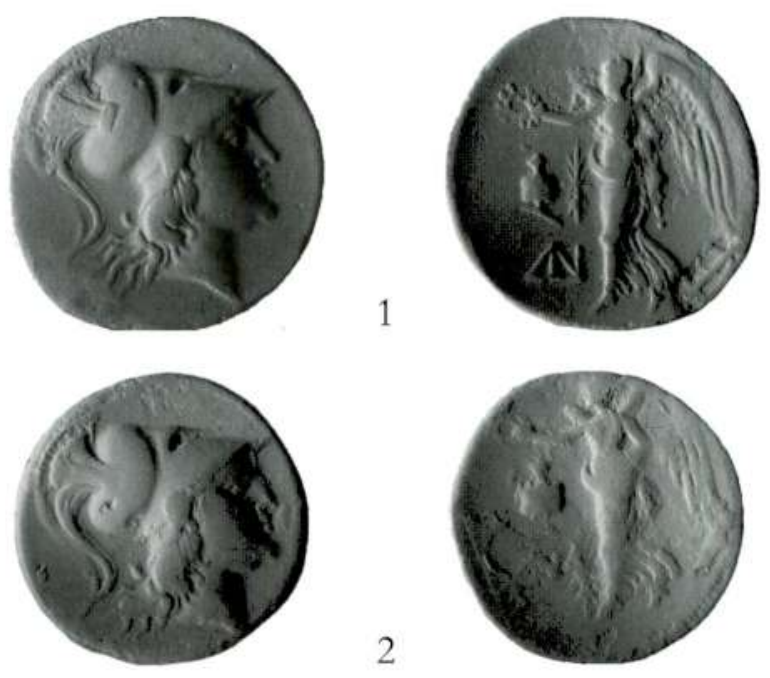

2
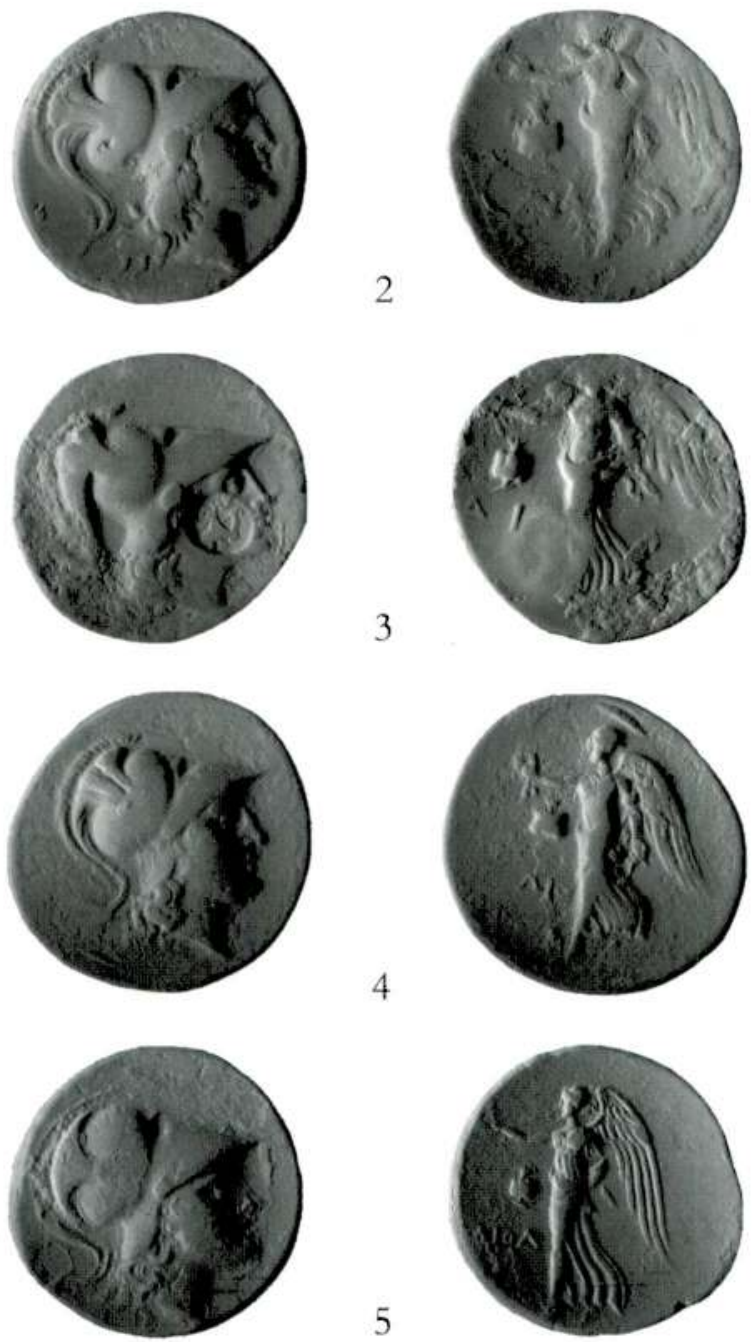

4

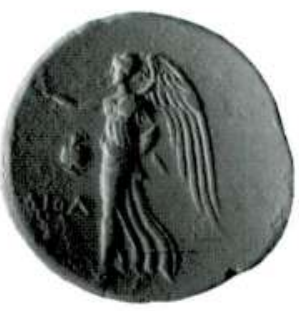

5 


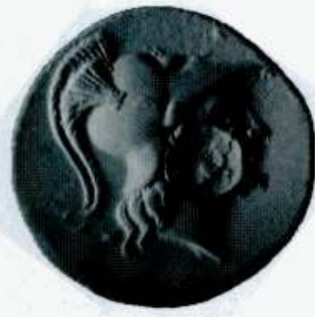

6
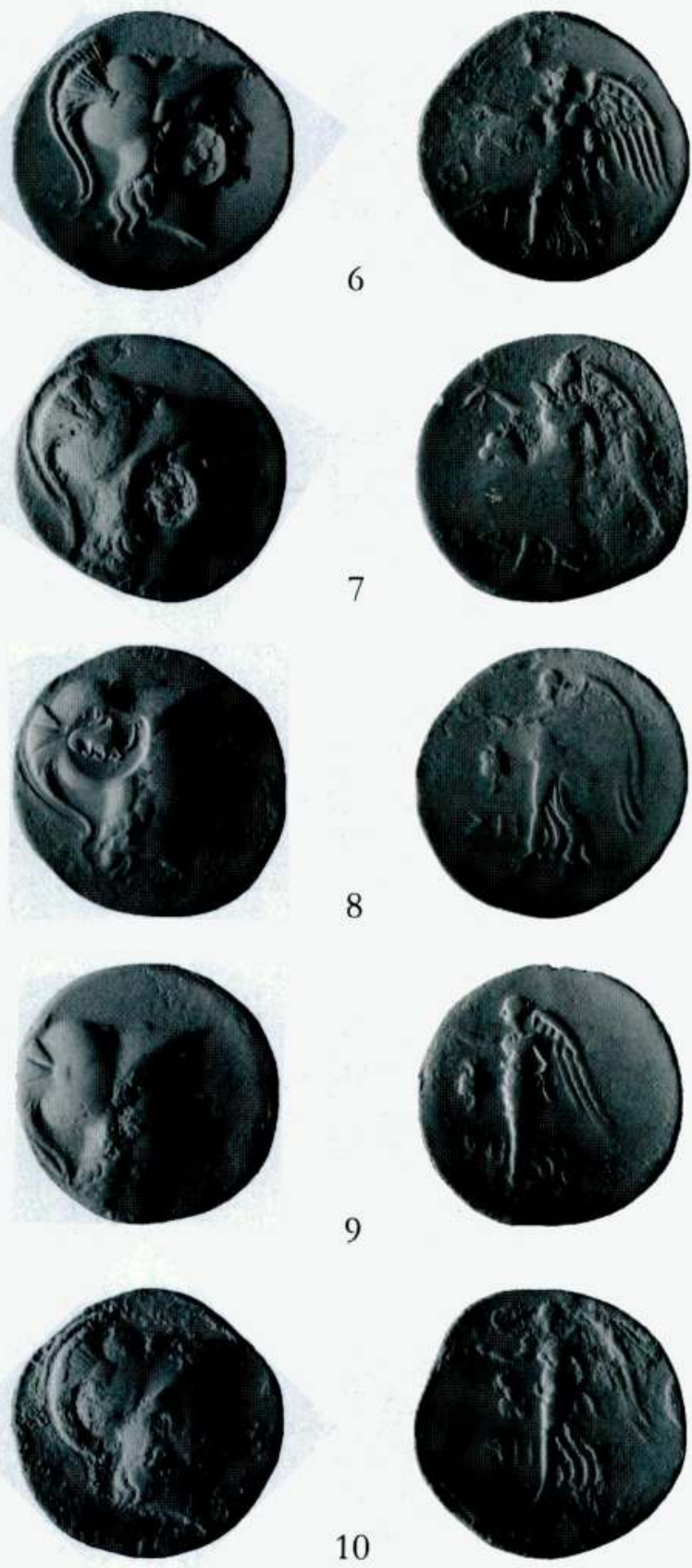

9
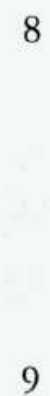

10

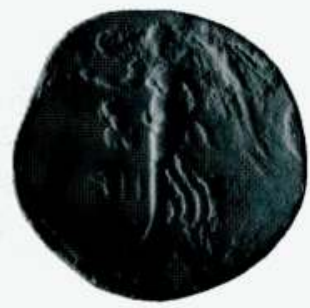




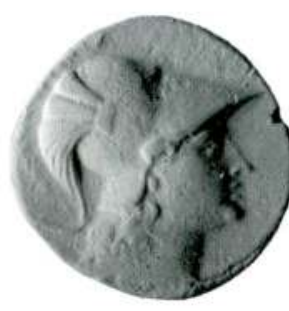

11
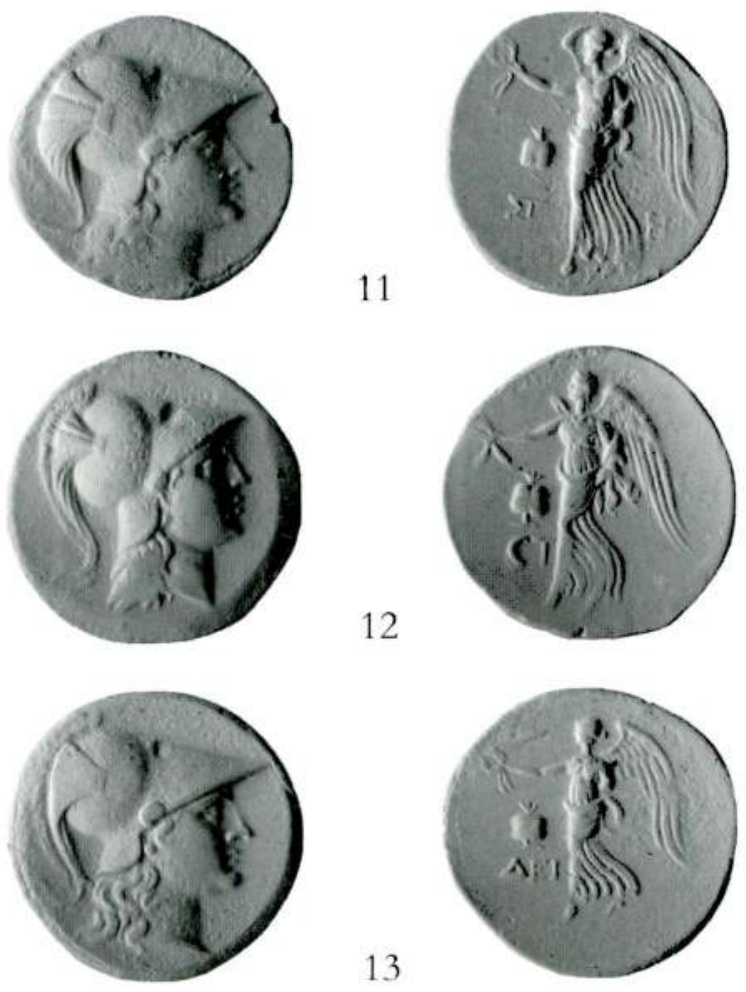

12

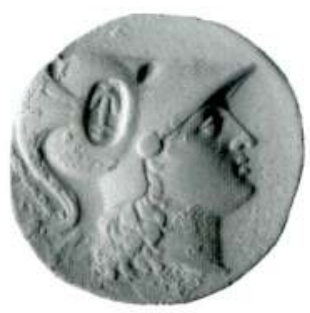

13
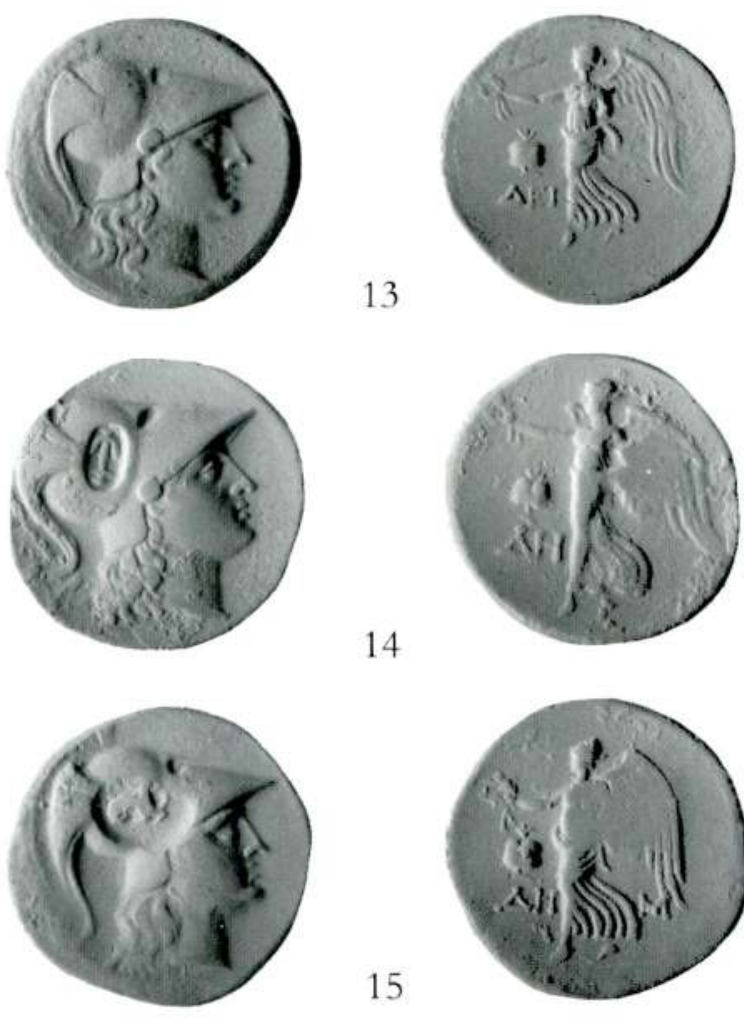

14

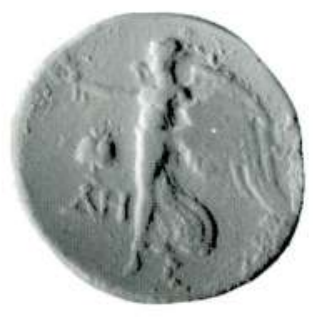

15

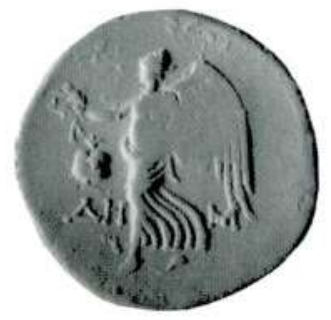




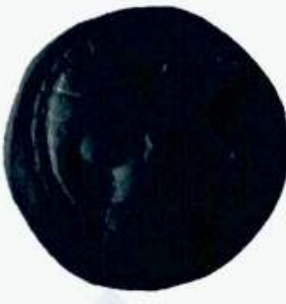

16
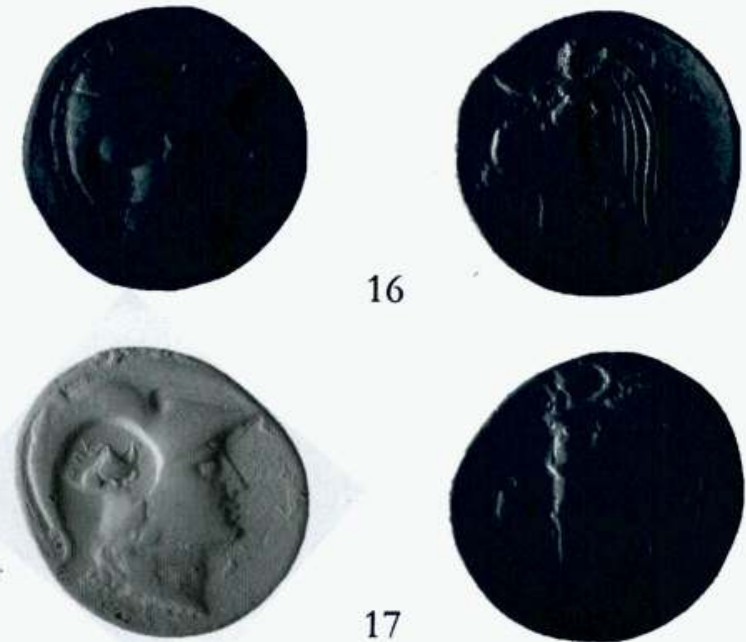

17
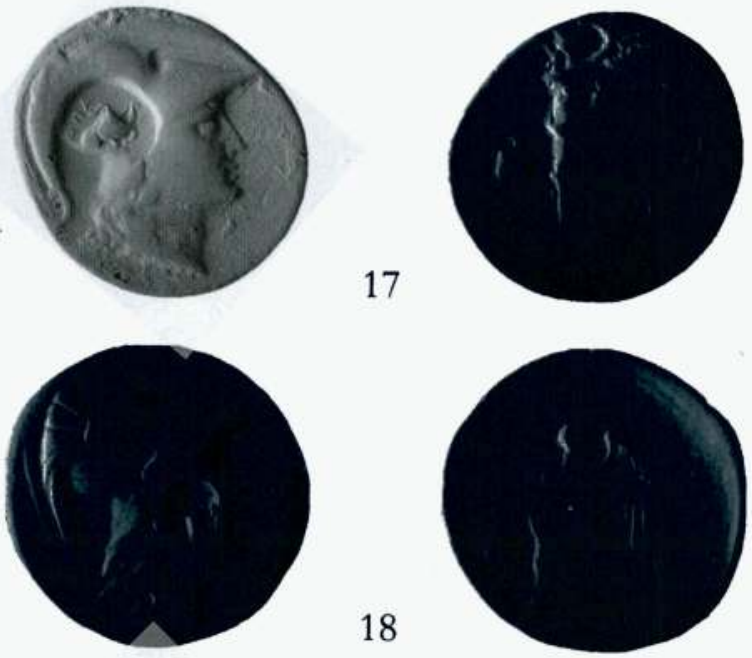

18
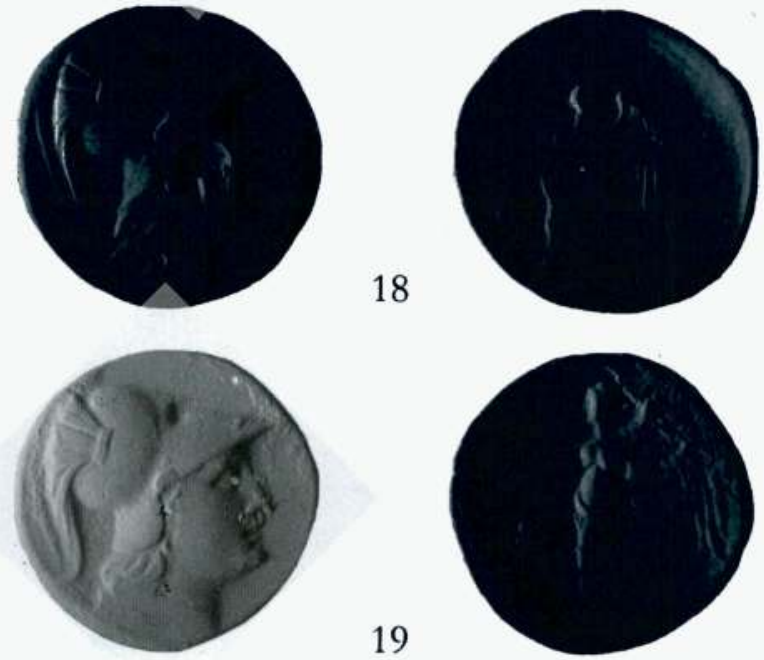

19

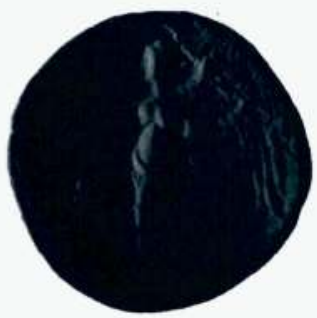

